\title{
Who Benefits from Regional Trade Agreements? The View from the Stock Market
}

\author{
Christoph Moser and Andrew K. Rose* \\ Draft: 01 April 2013
}

\begin{abstract}
The effects of Regional Trade Agreements (RTAs) are disputed. In this paper, we assess these effects using stock returns from a recent data set that spans over two hundred RTA announcements, eighty economies, and twenty years. We measure the effects of news concerning RTAs on the returns of national stock markets, after adjusting these returns for international stock market movements. We then link these abnormal returns to features of the RTA members and the agreements themselves. We find evidence of the natural trading partner hypothesis; stock markets rise more when RTAs are signed between countries that already engage in high volumes of trade. Stock markets also rise more when poorer countries sign RTAs, and when RTAs are signed with smaller partners. We also find no evidence that capital markets expect significant trade diversion effects.
\end{abstract}

Keywords: event, study, daily, assets, low, income, natural, panel, data, empirical

JEL codes: F10, F13, G14.

Contact: Christoph Moser

ETH Zurich

KOF Swiss Economic Institute

Weinbergstrasse 35

8092 Zurich

Tel: +41446328311

E-Mail: moser@kof.ethz.ch

URL: http://www.cer.ethz.ch/sturm/people/moserc/

\begin{abstract}
* The authors are respectively: post-doctoral researcher at ETH Zurich, KOF Swiss Economic Institute, and CESifo research affiliate; and B.T. Rocca Jr. Professor of International Trade, NBER research associate and CEPR research fellow. For comments, we thank: Jeff Bergstrand, Christian Conrad, Mark Copelovitch, Peter Egger, Martin Gassebner, Michael Lamla, Mario Larch, Emanuel Ornelas and participants of the $3^{\text {rd }}$ Volkswirtschaftlicher Workshop at the University of Tübingen, the CEEI-conference in Vienna, the University of Munich, the University of Lucerne, the University of Bayreuth, the University of Hohenheim, the Swiss Society of Economics and Statistics in Zurich, the Verein für Socialpolitik in Göttingen and the KOF Brown Bag Seminar.
\end{abstract}




\section{1: Introduction and Motivation}

Almost all economists favor trade liberalization. While multilateral liberalization has stalled lately, there has been an unprecedented rise in the number of Regional Trade Agreements (hereafter RTAs) over the last fifteen years. However, the consequences of RTAs are controversial. Are RTAs indeed a viable and desirable alternative to multilateral trade liberalization? In this empirical paper, we take a fresh look at this question and assess RTAs using the lens of the stock market. ${ }^{1}$

A large literature on RTAs has emerged; Freund and Ornelas (2009), Baldwin (2008) and Panagariya (2000) provide surveys. Some stylized facts emerge from the recent literature. RTAs tend to boost trade between their members, with small tradediverting effects for non-members. RTA formation is not random, but depends systematically on economic and political factors. Further, there is evidence of considerable heterogeneity in the overall trade effect of RTAs. ${ }^{2}$

The "natural trading partner hypothesis" suggests that positive welfare effects stem from RTAs between countries with high trade volumes prior to the agreement. The strength of the theory is a matter of controversy. Baier and Bergstrand (2004) and Egger and Larch (2008) find support for the hypothesis. In contrast, Krishna (2003) uses a general equilibrium model to argue that the welfare effects from potential RTAs with 24 trading partners of the United States are associated with neither trade volume between nor distance to RTA partners.

A few empirical studies go beyond the trade effects of RTAs. The welfare effects of the Canada-U.S. FTA and NAFTA on member and non-member countries have been assessed to be small and positive or close to zero according to Trefler (2004) and Romalis (2007). Based on a structural model, Egger and Larch (2011) find that positive welfare effects of the Europe Agreements are more pronounced for Central and Eastern European countries (CEEC) than for the older (15) members of the EU.

The theoretical impact of a RTA on the returns to capital (as measured by the stock market) depends crucially on the degree of capital mobility across sectors. 
Grossman (1983) offers a theoretical framework, where the Heckscher-Ohlin model and the specific-factor model emerge as two polar cases. With perfect capital mobility, overall stock market returns depend on a country's capital endowment relative to its RTA-partners. However, Grossman and Levinsohn (1989) provide evidence in favor of limited short-run capital mobility (and a specific-factor model). ${ }^{3}$ In this case, some industries (and the owners of their capital) might profit from a new RTA, while others potentially suffer. More generally, firm profits and RTAs can be related in different ways. On the one hand, profits may rise due: to 1) productivity gains within the firm or industry due to trade liberalization (e.g., Pavcnik, 2002; Melitz, 2003; Trefler, 2004; Lileeva and Trefler, 2010); 2) economies of scale that can be exploited in a bigger market, and/or 3) trade creation within the RTA. On the other hand, RTAs can enable costly trade diversion, and profits for some industries might fall due to increased import competition. ${ }^{4}$

In this paper, we are interested in the effect of important news about RTAs on the overall stock market. We examine national stock market reactions to RTAs for a number of reasons. First, stock prices should react quickly to news that changes the expected stream of discounted future dividends. Given that some firms might be expected to profit and others to suffer from lowering trade barriers, a country's stock market index captures the net effect on expected future profits of listed firms due to a RTA. Second, in case of trade liberalizations, short-term adjustments costs have to be weighed against long-term gains (e.g., Trefler, 2004). Both effects are hard to measure individually, but the stock market represents a natural way to measure the net present value of these counteracting effects. Third, there is little empirical evidence on the effects of trade liberalization on capital owners; the effects of trade on labor outcomes have attracted most of the profession's attention. Fourth, profits are arguably the most important firm performance variable, crucial for a firm's innovation, employment and survival. Nevertheless, there are only a small number of studies on profitability, as Wagner (2012) concludes in his survey.

We provide the first systematic evidence on the effects of RTAs on stock market returns. Our data set encompasses a large number of RTAs, countries, and years. 
Since we have a relatively large number of observations, we are able to differentiate across the countries that sign RTAs and the RTAs themselves, enabling us to link the impact of RTA news on stock market with the characteristics of both RTAs and countries. This enables us, for example, to examine whether poorer countries profit from RTAs. This is a matter of considerable controversy to eminent economists like Joseph Stiglitz, who are concerned that poorer countries face a "take-it-or-leave-it" attitude in negotiations with partners like the United States. ${ }^{5}$ We can also check the natural trading partner hypothesis, since our data set includes variation in trade links across trading partners.

The few empirical studies close to ours study the stock market reactions of individual firms. Thompson (1993, 1994), Rodriguez (2003) and Breinlich (2011) all exploit important news about the Canada-US free trade agreement and NAFTA. These papers use the stock market to study trade determination, and find evidence in favor of economies of scale, factor-intensity and heterogeneous firm models. Our work is complementary and distinct, focusing on the characteristics of RTAs and countries whose stock markets react to RTA news, rather than the nature of international trade.

Our approach remains unabashedly empirical, and uses standard empirical techniques. We find three robust results. First, RTAs tend to increase the stock market if they are signed with 'natural' trading partners. Second, the stock markets of poor countries rise more on RTA news than those of the rich. Third, returns are highest when RTAs are signed with smaller RTA-partners.

\section{2: The Data Set}

We consider all RTAs that have been signed, reported and enacted into force as of end of October 2009. The universe of RTAs is drawn from the "Regional Trade Agreement Information System" (RTA-IS) database of the World Trade Organization

(WTO), available at http://rtais.wto.org. ${ }^{6}$ However, data limitations prevent us from using data on all RTAs, as we discuss below. 


\section{News Announcements}

A central component of our data set and identification strategy consists of a unique set of dates. These are days of important news releases concerning individual RTAs. We consider two important dates: a) the day when it was announced that negotiations on a RTA will commence at some future date (which we dub "Start"), and b) the day that agreement on the RTA was actually reached ("Deal"). ${ }^{7,8}$ We identify the exact announcement dates through a full-text analysis on LexisNexis, where we mainly focus on international newswires, press releases and well-established newspapers published in English. ${ }^{9}$ Announcements of RTAs are usually made by prominent policy makers like the President, Prime Minister, or the Minister of Finance, Economics, or Trade. These dates often precede official signature dates (as reported by the WTO) by weeks or months. ${ }^{10}$ Announcements that are made over the weekend are advanced to register on the next business day. ${ }^{11}$

\section{Stock Markets and Exchange Rates}

Over 130 countries in the world have signed RTAs. Since we try to include as many observations as possible, one of the constraints on our data set is the fact that a number of countries have either no national stock market or have opened one only recently. To the best of our knowledge, we include all countries for which any daily stock market data are available since 1970.

Our default measure is the daily closing rate of a broad national stock market index, denominated in local currency. For example, we use: the S\&P500 for the American stock market, the FTSE for the UK, the DAX for Germany, the Nikkei for Japan, and the S\&P/TSX for Canada. We search for these series from a number of different data providers, and use them in a sequential order determined mostly by the span of the data and (our perceived) accuracy of the data set: Global Financial Database (which we use wherever possible); MSCI/Barra (which we use when reliable GFD data does not exist); Freelunch.com and the Standard \& Poors IFC (to fill in remaining gaps). ${ }^{12}$ 
While returns in local currency are those of greatest interest to local investors, they are not the only returns of interest. Foreign investors may be more interested in local returns after taking into account any coincident exchange rate changes.

Accordingly, we add to our data set daily closing spot exchange rates vis-à-vis the U.S. dollar; these allow us to convert stock market returns from local currency returns into U.S. dollar returns. Once again, we gather data from a number of different sources and use them in sequential order. We draw on exchange rate data from the U.S. Federal Reserve, and (via Datastream): Thomson Reuters, WM/Reuters, Global Treasury Information Systems (before 2000, these series come from Bankers Trust), and $\mathrm{MSCl}$.

National stock markets sometimes move in synchronization with international stock prices; we usually account for this feature. We use a few global stock market aggregates to adjust domestic returns for international movements. We primarily use the MSCI World index, though we also take advantage of the EAFE index (both measured in dollars). The MSCI World index covers all important stock markets around the world, while the EAFE focuses on developed stock markets outside the United States

We restrict ourselves to trading Monday through Friday. All series have been corrected after extensive checking for mistakes, transcription errors, jumps, the introduction of the Euro, and the like. ${ }^{13}$

We are left overall with a data set that covers 1001 country-RTA-events for 82 countries and 122 regional trade agreements. ${ }^{14}$ Online appendix table 1 provides detailed information on the announcement dates, the type of news and the countries included for each RTA in the data set.

\section{Country Characteristics}

To measure national economic and financial characteristics, we gather data from the World Bank's World Development Indicators which provides measures of country income, size and stock-market size. We add bilateral trade data taken from the IMF's Direction of Trade Statistics in order to measure openness and importance of trade. ${ }^{15}$ 


\section{3: Empirical Methodology}

We use a two-step empirical methodology. First, we adopt a standard eventstudy methodology to generate abnormal returns for domestic stock markets around the dates of RTA announcements. Second, we study why these returns differ by comparing them to the features of both the countries and the RTAs involved.

\section{Step 1: Creating Abnormal National Returns}

We are typically interested in a high-frequency return on the stock market around the time of RTA news, but only the idiosyncratic national component after adjusting for any common global stock market drift. We adjust national returns for international movement using the plain-vanilla "event study" methodology suggested by MacKinlay (1997). In particular, we regress daily national returns on daily global returns of the MSCI-World index so as to be able to estimate a national beta (capturing the comovement between the national and global stock markets) and an associated intercept (capturing any potential out- or under-performance of the national stock market relative to the world stock market). We do this separately for each country-RTA-event, using a window of time that starts thirteen months before the news event and ends a month before the announcement (in order to avoid allowing the estimation window to be influenced by the announcement itself). That is, we estimate over the relevant estimation window:

$$
R_{i, t}=\alpha_{i}+\beta_{i} R_{M S C l, t}+\varepsilon_{i, t} \quad \text { over } \mathrm{t}=\mathrm{T}-395 \ldots \mathrm{T}-29
$$

where: $R_{i, t}$ is the one-day return on the national stock market index of country i realized at the end of day $t, R_{M S C l, t}$ is the analogue for the MSCl-World index, $E\left(\varepsilon_{i, t}\right)=0$, $\operatorname{Var}\left(\varepsilon_{i, t}\right)=\sigma^{2}$, and $T$ is the day of the relevant RTA news announcement. 
After we estimate the coefficients $\left\{\hat{\alpha}_{i}, \hat{\beta}_{i}\right\}$ with least squares, we can then use them to form one-day abnormal returns $\left(A R_{i, t}\right)$ around the time of the RTA event. Our default measure of abnormal returns is thus the national return (measured in local currency) adjusted for global stock market drift as proxied by the $\mathrm{MSCl}$ dollar return:

$$
A R_{i t} \equiv R_{i t}-\hat{\alpha}_{i}-\hat{\beta}_{i} \cdot R_{\mathrm{MSCI}, t}
$$

We cumulate these abnormal returns over time around the dates of RTA announcements. Our default measure of cumulative abnormal return $\left(C A R_{i, t}\right)$ aggregates abnormal returns starting a day before the news event, and continuing through five business days (one week) afterward. That is, we form

$$
C A R_{i, T} \equiv \sum_{T-1}^{T+5} A R_{i, t}
$$

We test for robustness with respect to the exact window of time by cumulating for both fewer (one and three) and more (seven and ten) days after the RTA news event.

\section{Step 2: Linking National Returns to Fundamentals}

The first part of our methodology delivers a set of observations, each measuring the reaction of the stock market to a particular piece of RTA news for an individual country. However, our primary interest is not the intrinsic characteristics of these cumulative abnormal returns (hereafter CARs). Rather, we seek to understand why these returns vary across countries and RTAs; we ask why the stock market responds more to news about certain countries and/or RTAs than to others? We estimate the following equation: ${ }^{16}$ 


$$
C A R_{i, T}=\gamma \cdot N A T_{i, T}+\delta \cdot R T A_{i, T}+u_{i, T}
$$

where: $N A T_{i, T}$ denotes a set of characteristics of country $i$ at time $T, R T A_{i, T}$ is a set of characteristics describing the nature of the RTA signed by the country at the time, $u_{i, T}$ is a well-behaved residual and $\{\gamma, \delta\}$ are the (vectors of) coefficients of interest to us. We estimate (4) with least squares on the assumption that the disturbance represents a host of well-behaved terms that drive the national stock market independently of the included regressors. We use standard errors clustered at the country-level. ${ }^{17}$

The economic literature offers us little guidance with respect to the regressors in equation (4). Our choice of variables is ad hoc but intuitive.

We are interested in whether the macroeconomic characteristics of a country affect the response of the stock market to RTA news. Accordingly, as (NAT) regressors in (4) we include:

1. (the natural logarithm of) real GDP per capita, since poorer countries might lack the bargaining power in negotiations to benefit from RTAs,

2. (log) real GDP (economic size), another proxy for a country's ability to extract benefit from a RTA, and a key variable in traditional empirical gravity models,

3. the (log of the) ratio of nominal trade to GDP (openness), since the liberalization of a closed economy sends a stronger signal of economic reform, and

4. the (log of the) ratio of stocks traded to GDP, since it is well known from the finance literature that expected stock market returns and liquidity are positively related and stock markets tend to be less liquid in developing countries (e.g., Amihud, 2002; Karolyi et al., 2012). ${ }^{18}$

We are also interested in whether features of the RTA drive the stock market reaction. We do this by including as (RTA) regressors in (4): 
1. the ratio of bilateral exports to RTA partners/GDP, since current (and potential) exports can benefit more from a RTA; a positive coefficient would indicate support for the "natural" trading partner hypothesis, ${ }^{19}$ and

2. the (log of the) sum of real GDPs of RTA trading partners. This represents a different measure of RTA importance. This effect is, in principle, ambiguously signed since trade and its benefits grow with the size of the RTA (consistent with the gravity model), but the ability of a country to extract these benefits may shrink as the foreign part of the RTA grows (as Joseph Stiglitz worries). ${ }^{20}$

Thus in the second stage, we regress the CARs on four national and two RTA characteristics. Throughout, we include in (4): time-fixed effects, an intercept and a dummy that differentiates RTAs that cover trade in goods and services (rather than simply goods).

\section{4: Results}

\section{First Evidence on Stock Market Returns}

We begin by presenting graphical evidence of the event study methodology which constitutes the first step of the methodology. Graph 1 plots the average CARs around the RTA events as a black solid line (with the corresponding $90 \%$ confidence intervals as grey dashed lines). The shaded area marks the baseline event window from $t-1$ to $t+5$. For event days before the RTA announcement, we follow Dube et al. (2012) and aggregate from the beginning of the event window, $t-1$, backwards.

CARs are never significantly different from zero before the RTA events, but are small, positive and, for many time periods, statistically significant for up to two-and-half weeks after the event. While Graph 1 offers insights into the dependent variable of equation (4) for different event windows, the main focus of this paper is on explaining the variation in abnormal returns. We turn to the second stage of the event study now.

\section{Benchmark Results}


We tabulate our default estimates of equation (4) in Table 1. The middle column presents results for our default window, which begins one day before the news announcement and extends until five days afterwards. To check for sensitivity we consider both longer and shorter windows; these are presented on either side of our default.

A country's size, openness, and stock market depth play little important role in explaining stock market returns across different RTA announcements. Still, we find three interesting results. First, there is a strong negative effect of national income; the stock markets of poor countries rise more with RTA news than do those of rich countries. ${ }^{21}$ This effect is statistically significant at conventional levels. It is also economically large; for our default window of $(\mathrm{t}-1, \mathrm{t}+5)$, an increase in per capita income of one standard deviation around the average level of real GDP per capita lowers abnormal returns by an annualized $10 \%$ (this effect is larger if we use a shorter window of time). This result echoes and generalizes the results of Baier and Bergstrand (2009). Finally, this result is sensible; poorer countries are more protectionist than richer ones, and thus have more to gain from trade liberalization.

Second, we find a strong effect for the impact of normalized exports to RTA members, consistent with the "natural trading partner" hypothesis. This effect is consistently statistically significant, and economically large; an increase in the RTA export to GDP ratio of one standard deviation from the mean delivers annualized returns of around $10 \% .{ }^{22,23}$ This finding is in line with the empirical literature on trade flows and extends it to expected profits.

The effect of RTA-partner's log real GDP is statistically significant and negative, implying that annualized returns are depressed by about $10 \%$ for a change of one standard deviation from the mean. That is, Stiglitz's concern about the negotiating power of large RTA-partner(s) might be warranted (unreported results show that the United States and the European Union do not drive this result). ${ }^{24}$

Appendix Graphs 1 to 3 plot the coefficients for our three main results for each potential event window starting from $(t-20, t-1)$ over our default window $(t-1, t+5)$ marked 
as a grey shaded area up to the last event window considered $(t-1, t+20)$. While the effects on poorer countries and large RTA-partners become insignificant after about two-and-half weeks, the positive stock market effect for natural trading partner seems to persist for a longer period.

\section{Sensitivity Analyses}

We have found that the stock markets of poorer countries respond more to RTA news; RTAs between countries with proportionately more exports also experience a more pronounced stock market effect; and large RTA-partners tend to reduce stock market returns. On the other hand, the economic size, openness and financial depth of the country signing the RTA seem irrelevant to the markets. Are these results sensitive to a number of perturbations in the baseline specification? In a word, "no," as we now document.

To check for sensitivity of the computation of our default measure of abnormal returns, we provide a number of alternative techniques to adjust national for global returns. Table 2 compares results from our default regressand with four alternatives. First, we substitute EAFE returns (a more narrow measure of the global stock market index, which excludes the United States) for those of the MSCl. Next, we restrict $\beta_{i}$ in equation (1) to lie in the range of $(-1,1)$ in order to curb the responsiveness of the national stock market to international returns. Third, we set $\alpha_{i}=\beta_{i}=0$ and thus do not adjust for global returns at all and use the raw returns in local currency instead. Finally, we scale abnormal returns by the standard deviation of the residuals of the estimation window to limit the influence of volatile stock market observations (coefficients change due to smaller mean and variation of regressand). ${ }^{25}$ None of these perturbations substantively changes our results. ${ }^{26}$

Our default measure of national returns is measured as a percentage change in local currency. In Table 3 we show that currency fluctuations do not account for our results. First, we convert LC to US\$ returns and report results for US dollar returns both unadjusted, and adjusted to global returns; alternatively, we add the LC/\$ exchange change to the $\mathrm{MSCl}$ return in equation (1). Our results seem insensitive. ${ }^{27}$ 
In Table 4 we check our results by varying the fixed effects. First, we exclude time-specific fixed effects. Another column reports adding controls for the type of RTA to the baseline; we differentiate customs unions, free trade agreements, and preferential trade agreements. Next we add a fixed effect for each country. Finally, we include fixed effects for each RTA (e.g., NAFTA, which affects the stock markets of Canada, Mexico, and the USA). Only the inclusion of country-fixed effects has a non-trivial effect; the export effect is unchanged, but there is too little variation within a country over time to identify the effects of national variables.

Finally, in Appendix Tables 5 and 6, we add a number of additional control variables on the RTA-partner or country $i$. Most of these variables are not significant and our main results are robust to their inclusion.

\section{Evidence for (Expected) Trade Diversion?}

Our analysis so far suggests that listed firms in RTA-member countries are, on average, expected to profit from RTAs. While an analysis of potential winners and losers within RTA-member countries is beyond this study, this section sheds some light on a related question of importance: Do the gains of RTA-members come at the expense of countries outside the RTA? That is, do market participants expect measurable trade (or profit) diversion effects?

We consider cases like the following. The United States has been one of Brazil's top export destinations over the last 20 years, but these two countries are not linked by a RTA. How did the Brazilian stock market react to important news about NAFTA (a RTA that involved the United States)? For such non-RTA-member countries we compute abnormal returns and link them to the set of variables used in the main specification. ${ }^{28}$ We expect the coefficient on the export variable to be negative for serious expected trade or profit diversion effects of non-RTA-members

Column (1) of Table 5 replicates the baseline and columns (2) to (5) show the results for different definitions of an important export destination. The coefficient of main interest on exports is never significantly different from zero in any specification. 
Financial market participants do not seem to price in any negative spill-over effects to non-RTA-members. This is also perfectly in line with the empirical trade literature. Freund and Ornelas (2009) conclude in their excellent survey that trade diversion does not seem to be a major concern, even though it might matter for some RTAs or in certain sectors.

Table 5 also includes a placebo test. Keep in mind that columns (2) to (5) refer to stock market reactions in countries without an important RTA-news on the very same day of other countries making such announcements. If on these event-days anything favorable to poor countries and unobservable to the econometrician (and hence not captured by the market model) happened to poorer countries, we would expect a negative and significant coefficient on Log Real GDP p/c. This is never the case.

\section{5: Summary}

In this empirical paper, we have assessed the effects of Regional Trade Agreements (RTAs) from a new vantage point, that of the stock market. We use a twostep methodology to analyze a new comprehensive daily data set that includes 1001 observations spanning 82 economies, 199 announcements and 122 RTAs between 1988 and 2009. First, we measure the effects of RTA news on the returns of national stock markets, after adjusted for international stock market movements in a variety of ways using an event-study methodology. Then we link these abnormal returns to features of both the RTA participants and those of the agreement itself. We find strong robust evidence of the natural trading partner hypothesis; stock markets rise more for RTAs between countries that engage in high volumes of trade. Stock markets respond more to RTAs signed by poorer countries, and more to RTAs signed with small RTApartners. We do not find any evidence that expected trade or profit diversion effects are important to non-RTA-members. A better understanding of the underlying channels responsible for these effects is a fruitful field for future research. 


\section{References}

Amihud, Yakov (2002), "Illiquidity and Stock Returns: Cross-section and Time-series Effects," Journal of Financial Markets, Vol. 5, pp. 31-56.

Baier, Scott and Jeffrey Bergstrand (2004), "Economic Determinants of Free Trade Agreements," Journal of International Economics, Vol. 64, pp. 29-63.

Baier, Scott and Jeffrey Bergstrand (2007), "Do Free Trade Agreements actually Increase Members' International Trade?" Journal of International Economics, Vol. 71, pp. 72-95,

Baier, Scott and Jeffrey Bergstrand (2009), "Estimating the Effects of Free Trade Agreements on International Trade Flows Using Matching Econometrics," Journal of International Economics, Vol. 77, pp. 63-76.

Baldwin, Richard (2008), "Big-Think Regionalism: A Critical Survey," NBER Working Paper, No. 14056.

Baldwin, Richard and Dany Jaimovich (2012), "Are Free Trade Agreements Contagious?" Journal of International Economics, Vol. 88, pp. 1-16.

Bernard, Andrew, Bradford Jensen. Stephen Redding and Peter Schott (2007), "Firms in International Trade," Journal of Economic Perspectives, Vol. 21, pp. 105-130.

Carrère, Cèline (2006), "Revisiting the Effects of Regional Trade Agreements on Trade Flows with Proper Specification of the Gravity Model," European Economic Review, Vol. 50, pp. 223-247.

Dube, Arindrajit, Ethan Kaplan and Suresh Naidu (2011), "Coups, Corporations, and Classified Information," Quarterly Journal of Economics, Vol. 126, pp. 1375-1409.

Eicher, Theo, Christian Henn and Chris Papageorgiou (2012), "Trade Creation and Diversion Revisited: Accounting for Model Uncertainty and Natural Trading Partner Effects," Journal of Applied Econometrics, Vol. 27, pp. 296-321. 
Egger, Peter and Mario Larch (2008), "Interdependent Preferential Trade Agreement Memberships: an Empirical Analysis," Journal of International Economics, Vol. 76, pp. 384-399.

Egger, Peter and Mario Larch (2011), "An Assessment of the Europe Agreements' Effects on Bilateral Trade, GDP, and Welfare," European Economic Review, Vol. 55, pp. 263-279.

Egger, Peter, Mario Larch, Kevin Staub and Rainer Winkelmann (2011), "The Trade Effects of Endogenous Preferential Trade Agreements," The American Economic Journal: Economic Policy, Vol. 3, pp. 113-143.

Freund, Caroline and Emanuel Ornelas (2009), "Regional Trade Agreements," CEP Discussion Paper No. 961, Centre for Economic Performance.

Grossman, Gene (1983), "Partially Mobile Capital - General Approach to Two-sector Trade Theory," Journal of International Economics, Vol. 15, pp. 1-17.

Grossman, Gene and James Levinsohn (1989), "Import Competition and the Stock Market Return to Capital," American Economic Review, Vol. 1065-1087.

Kolari, James and Seppo Pynnönen (2010), "Event study testing with cross-section correlation of abnormal returns," Review of Financial Studies, Vol. 23, pp. 3996-4025.

Karolyi, Andrew, Kuan-Hui Lee and Mathijs van Dijk (2012), "Understanding Commonality in Liquidity Around the World," Journal of Financial Economics, Vol. 105, pp. 82-112.

Kothari, S.P. and Jerold Warner (2007), "Econometrics of Event Studies," in: Handbook of Corporate Finance, ed.: Espen Eckbo, Vol. 1, pp. 3-36.

Krishna, Pravin (2003), "Are Regional Trade Partners "Natural"?" Journal of Political Economy, Vol. 111, pp. 202-226. 
Lileeva, Alla, and Daniel Trefler (2010), "Improved Access to Foreign Markets Raises Plant-level Productivity ... for Some Plants," Quarterly Journal of Economics, Vol. 125, pp. 1051-1099.

Magee, Christopher (2003), "Endogenous Preferential Trade Agreements: An Empirical Analysis," Berkeley", Contributions to Economic Analysis and Policy, Vol. 2, Article 15, Berkeley Electronic Press.

Magee, Christopher (2008), "New Measures of Trade Creation and Trade Diversion," Journal of International Economics, Vol. 75, pp. 349-362.

MacKinlay, Craig (1997), "Event Studies in Economics and Finance," Journal of Economic Literature, Vol. 35, pp. 13-39.

Melitz, Marc, (2003), "The Impact of Trade on Intra-Industry Reallocations and Aggregate Industry Productivity," Econometrica, Vol. 71, pp. 1695-1725.

Pagano, Marco, Fabio Panetto and Luigi Zingalis (1998), "Why Do Companies Go Public? An Empirical Analysis," Journal of Finance, Vol. 53, pp. 27-64.

Panagariya, Arvind (2000), "Preferential Trade Liberalization: The Traditional Theory and New Developments," Journal of Economic Literature, Vol. 38, pp. 287-331.

Pavcnik, Nina (2002), "Trade Liberalization, Exit, and Productivity Improvements:

Evidence from Chilean Plants," Review of Economic Studies, Vol. 69, pp. 245-276.

Prabhala, N.R. (1997), "Conditional Methods in Event Studies and an Equilibrium Justification for Standard Event-Study Procedures," Review of Financial Studies, Vol. 10, pp. 1-38.

Rodriguez, Peter (2003), "Investor Expectations and the North American Free Trade Agreement," Review of International Economics, Vol. 11, pp. 206-218.

Romalis, John (2007), "NAFTA's and CUSFTA's Impact on International Trade," Review of Economics and Statistics, Vol. 89, pp. 416-435. 
Thompson, Aileen (1994), "Trade Liberalization, Comparative Advantage, and Scale Economies: Stock Market Evidence from Canada," Journal of International Economics, Vol. 37, pp. 1-27.

Trefler, Daniel (2004), "The Long and Short of the Canada-U.S. Free Trade Agreement," American Economic Review, Vol. 94, pp. 870-895.

Wagner, Joachim (2012), "International Trade and Firm Performance: A Survey of Empirical Studies since 2006," Review of World Economics, Vol. 148, pp. 235-267. 


\section{Graph 1: First stage of Event Study (Cumulative Abnormal Returns around RTA Events)}

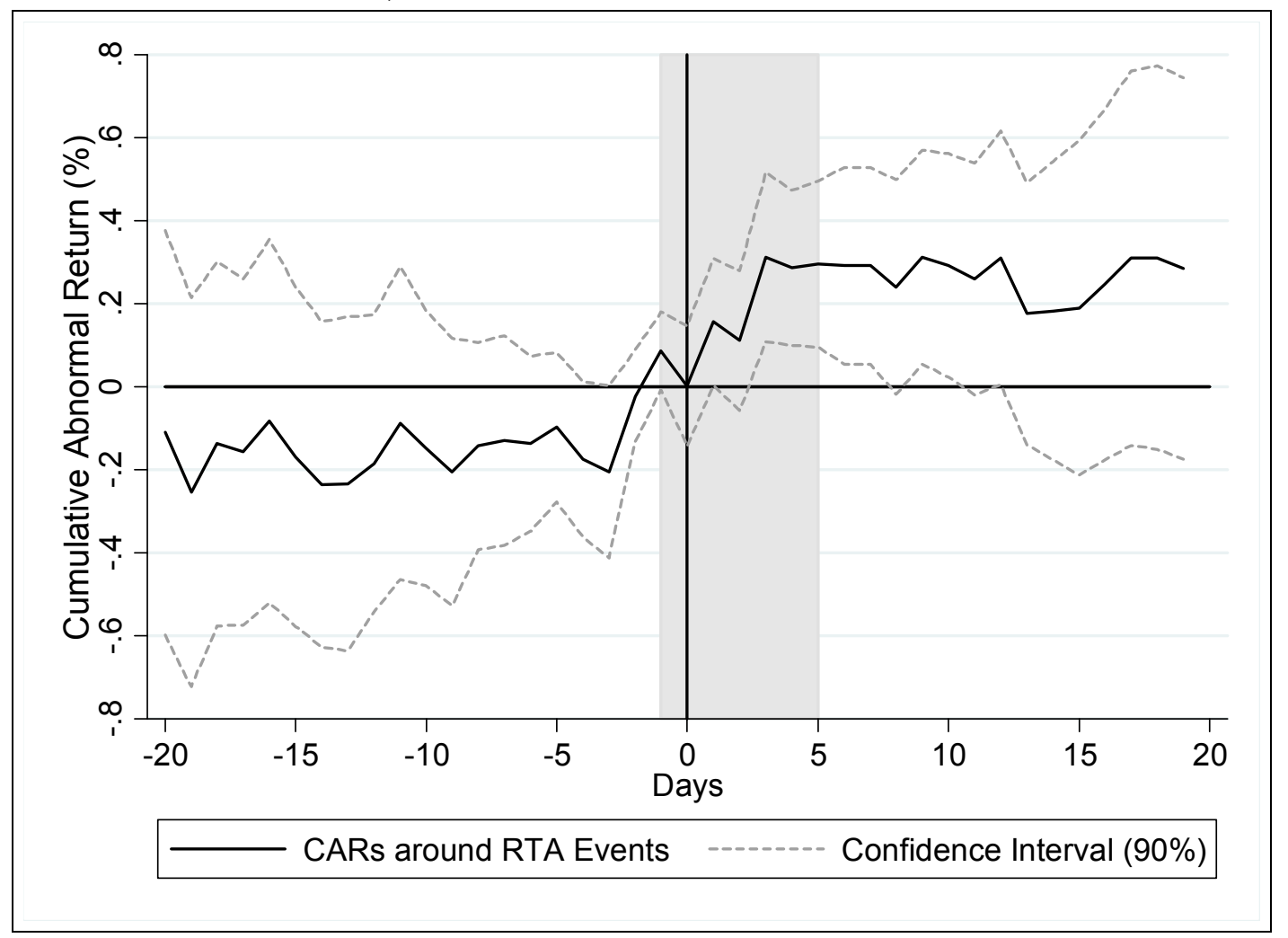

\section{Table 1: Default - Stock Market Returns in Local Currency}

\begin{tabular}{|l|c|c|c|c|c|}
\hline \hline Event window & $(\mathbf{t}-\mathbf{1}, \mathbf{t}+\mathbf{1})$ & $\mathbf{( t - 1 , \mathbf { t } + 3 )}$ & $\mathbf{( t - 1 , \mathbf { t } + \mathbf { 5 } )}$ & $\mathbf{( t - 1 , \mathbf { t } + 7 )}$ & $\mathbf{( t - 1 , \mathbf { t } + 1 0 )}$ \\
\hline Log real GDP p/c & $-0.172^{*}$ & $-0.191^{\circ}$ & $-0.248^{*}$ & $-0.302^{*}$ & $-0.302^{\circ}$ \\
\hline Log real GDP & $(0.08)$ & $(0.10)$ & $(0.12)$ & $(0.13)$ & $(0.17)$ \\
\hline Log Trade/GDP & 0.020 & 0.016 & 0.042 & 0.081 & 0.157 \\
& $(0.04)$ & $(0.05)$ & $(0.08)$ & $(0.10)$ & $(0.12)$ \\
\hline Log National Stocks/GDP & -0.094 & -0.065 & -0.099 & 0.177 & 0.207 \\
\hline & $(0.09)$ & $(0.10)$ & $(0.16)$ & $(0.19)$ & $(0.24)$ \\
\hline Exports to RTA partners/GDP & 0.058 & 0.069 & 0.043 & 0.011 & -0.019 \\
\hline & $(0.05)$ & $(0.07)$ & $(0.08)$ & $(0.10)$ & $(0.13)$ \\
\hline RTA-partner's log real GDP & $1.563^{* *}$ & $1.550^{*}$ & $2.620^{* *}$ & $2.178^{*}$ & $3.060^{* *}$ \\
\hline \hline
\end{tabular}

Note: Each column is estimated via OLS. Estimates based on 1001 observations, covering 82 developing and developed countries and 122 RTAs from 1988 to 2009. Event date defined as announcement of the start of negotiations of RTA or announcement of a successful conclusion of such an agreement. Coefficients with standard errors clustered at country-level in parentheses. Coefficients significantly different from zero at [0.10] 0.05 (0.01) marked with [one circle] one (two) asterisk(s). Regressand: National Stock Market return in local currency, adjusted for MSCI movement. Time-fixed effects, intercepts and Goods/Goods\&Services dummy included but not reported. 
Table 2: Different Measures of Stock Market Returns (in LC)

\begin{tabular}{|c|c|c|c|c|c|}
\hline Model & Default & $\begin{array}{r}\text { Beta adj. } \\
\text { (EAFE) }\end{array}$ & $\begin{array}{c}\text { Beta in }(-1,1) \\
\text { (MSCI) }\end{array}$ & $\begin{array}{c}\text { No beta adj. } \\
\text { (MSCI) }\end{array}$ & $\begin{array}{c}\text { Scaled, adj. } \\
\text { (MSCI) }\end{array}$ \\
\hline \multirow[t]{2}{*}{ Log real GDP p/c } & $-0.248^{*}$ & $-0.285^{*}$ & $-0.266^{*}$ & $-0.474^{* *}$ & $-0.070^{*}$ \\
\hline & $(0.12)$ & $(0.12)$ & $(0.12)$ & $(0.12)$ & $(0.03)$ \\
\hline \multirow[t]{2}{*}{ Log real GDP } & 0.042 & 0.021 & 0.070 & 0.029 & 0.032 \\
\hline & $(0.08)$ & $(0.08)$ & $(0.09)$ & $(0.09)$ & $(0.02)$ \\
\hline \multirow[t]{2}{*}{ Log Trade/GDP } & -0.099 & -0.073 & -0.100 & -0.084 & 0.004 \\
\hline & $(0.16)$ & $(0.15)$ & $(0.17)$ & $(0.23)$ & $(0.06)$ \\
\hline \multirow[t]{2}{*}{ Log National Stocks/GDP } & 0.043 & 0.050 & 0.041 & 0.120 & 0.012 \\
\hline & $(0.08)$ & $(0.08)$ & $(0.09)$ & $(0.10)$ & $(0.02)$ \\
\hline \multirow{2}{*}{ Exports to RTA partners/GDP } & $2.620^{* *}$ & $2.416^{* *}$ & $2.917^{* *}$ & $2.709^{*}$ & $0.938^{* *}$ \\
\hline & $(0.79)$ & $(0.80)$ & $(0.85)$ & $(1.06)$ & $(0.33)$ \\
\hline \multirow[t]{2}{*}{ RTA-partner's log real GDP } & $-0.153^{* *}$ & $-0.179 * *$ & $-0.166^{* *}$ & $-0.151^{*}$ & $-0.044^{*}$ \\
\hline & $(0.06)$ & $(0.06)$ & $(0.06)$ & $(0.06)$ & $(0.02)$ \\
\hline Number of Observations & 1001 & 1001 & 879 & 1001 & 1001 \\
\hline
\end{tabular}

Note: Each column is estimated via OLS; $(\mathrm{t}-1, \mathrm{t}+5)$ event window. Estimates in Column (1) show the baseline results from Table 1 for comparability, covering 82 developing and developed countries and 122 RTAs from 1988 to 2009. Column (2) displays results for national stock market returns adjusted for EAFE movement. In Column (3), sample is restricted to observations with betas between -1 and +1 (MSCI). Column (4) reports results for local returns without betaadjustment. Column (5) reports results for scaled excess returns (MSCI), whereby excess returns are divided by residual standard deviation of estimation window. Event date defined as announcement of the start of negotiations of RTA or announcement of a successful conclusion of such an agreement. Coefficients with standard errors clustered at the country-level in parentheses. Coefficients significantly different from zero at [0.10] 0.05 (0.01) marked with [one circle] one (two) asterisk(s). Regressand: National Stock Market return in local currency, adjusted for MSCI movement (unless indicated otherwise). Time-fixed effects, intercepts and Goods/Goods\&Services dummy included but not reported. 
Table 3: Different Adjustments of Stock Market Returns for Exchange Rates

\begin{tabular}{|l|c|c|c|c|c|}
\hline \hline Model & Default & $\begin{array}{c}\text { Stock returns } \\
\text { in LC }\end{array}$ & $\begin{array}{c}\text { No beta adj. } \\
\text { (USD) }\end{array}$ & $\begin{array}{c}\text { Beta adj. } \\
\text { (USD) }\end{array}$ & $\begin{array}{c}\text { Adjusted for } \\
\text { MSCI and FX }\end{array}$ \\
\cline { 2 - 6 } Log real GDP p/c & $-0.248^{*}$ & $-0.230^{\circ}$ & $-0.383^{* *}$ & $-0.322^{*}$ & $-0.368^{* *}$ \\
\hline Log real GDP & $(0.12)$ & $(0.13)$ & $(0.13)$ & $(0.15)$ & $(0.14)$ \\
\hline Log Trade/GDP & 0.042 & 0.041 & 0.056 & 0.026 & 0.080 \\
\hline Log National Stocks/GDP & $(0.08)$ & $(0.08)$ & $(0.09)$ & $(0.10)$ & $(0.10)$ \\
\hline & -0.099 & -0.203 & -0.335 & $-0.491^{\circ}$ & -0.119 \\
\hline Exports to RTA partners/GDP & $(0.16)$ & $(0.15)$ & $(0.26)$ & $(0.27)$ & $(0.19)$ \\
\hline & 0.043 & 0.059 & $0.173^{\circ}$ & 0.154 & 0.097 \\
\hline RTA-partner's log real GDP & $(0.08)$ & $(0.08)$ & $(0.09)$ & $(0.10)$ & $(0.10)$ \\
\hline & $-0.620^{* *}$ & $2.703^{* *}$ & $2.943^{*}$ & $2.726^{*}$ & $2.303^{*}$ \\
\hline Number of Observations & $(0.79)$ & $(0.81)$ & $(1.31)$ & $(1.28)$ & $(1.02)$ \\
\hline \hline
\end{tabular}

Note: Each column is estimated via OLS; $(t-1, t+5)$ event window. Estimates in Column (1) show the baseline results from Table 1 for comparability, covering 82 developing and developed countries and 122 RTAs from 1988 to 2009. In Column (2), sample is restricted to observations, where national stock market returns are available in local currency and U.S. dollar. Columns (3) and (4) report results for U.S. dollar returns without and with adjustment, respectively. Column (5) displays results for national stock market returns adjusted for MSCI and exchange rate movement. Event date defined as announcement of the start of negotiations of RTA or announcement of a successful conclusion of such an agreement. Coefficients with standard errors clustered at the country-level in parentheses. Coefficients significantly different from zero at [0.10] 0.05 (0.01) marked with [one circle] one (two) asterisk(s). Regressand: National Stock Market return in local currency, adjusted for MSCI movement (unless indicated otherwise). Time-fixed effects, intercepts and Goods/Goods\&Services dummy included but not reported. 
Table 4: Various Fixed Effects

\begin{tabular}{|l|c|c|c|c|c|}
\hline \hline \multirow{2}{*}{ Model } & Default & $\begin{array}{c}\text { Without time- } \\
\text { fixed effects }\end{array}$ & $\begin{array}{c}\text { RTA-type } \\
\text { dummies }\end{array}$ & $\begin{array}{c}\text { Country- } \\
\text { fixed effects }\end{array}$ & $\begin{array}{c}\text { RTA-fe } \\
\text { effects }\end{array}$ \\
\cline { 2 - 6 } & $-0.248^{*}$ & $-0.219^{\circ}$ & $-0.199^{\circ}$ & 3.487 & $-0.264^{\circ}$ \\
\hline Log real GDP p/c & $(0.12)$ & $(0.11)$ & $(0.11)$ & $(5.40)$ & $(0.15)$ \\
\hline Log real GDP & 0.042 & 0.034 & 0.021 & -2.336 & 0.115 \\
\hline Log Trade/GDP & $(0.08)$ & $(0.07)$ & $(0.07)$ & $(4.47)$ & $(0.13)$ \\
\hline Log National Stocks/GDP & -0.099 & -0.058 & -0.146 & 0.756 & 0.163 \\
\hline & $(0.16)$ & $(0.17)$ & $(0.16)$ & $(0.92)$ & $(0.28)$ \\
\hline Exports to RTA partners/GDP & 0.043 & 0.032 & 0.034 & -0.020 & 0.073 \\
\hline RTA-partner's real GDP & $(0.08)$ & $(0.08)$ & $(0.08)$ & $(0.19)$ & $(0.09)$ \\
\hline Number of Observations & $2.620^{* *}$ & $2.456^{* *}$ & $2.649^{* *}$ & $2.696^{* *}$ & $1.769^{\circ}$ \\
\hline \hline
\end{tabular}

Note: Each column is estimated via OLS; $(t-1, t+5)$ event window. Estimates in Column (1) show the baseline results from Table 1 for comparability, covering 82 developing and developed countries and 122 RTAs from 1988 to 2009. Column (2) drops time-fixed effects to baseline. In Column (3), the dummy variables Currency Union and Free Trade Agreement are included, but not reported (with Preferential Trade Agreement being the leave-out categoy). Columns (4) and (5) employ country-fixed effects and RTA-fixed effects. Event date defined as announcement of the start of negotiations of RTA or announcement of a successful conclusion of such an agreement. Coefficients with standard errors clustered at the country-level in parentheses. Coefficients significantly different from zero at [0.10] 0.05 (0.01) marked with [one circle] one (two) asterisk(s). Regressand: National Stock Market return in local currency, adjusted for MSCI movement. Time-fixed effects (except for column 2), intercepts and Goods/Goods\&Services dummy variable included but not reported. 


\section{Table 5: Non-RTA-members Stock Market Returns - Expected Trade} Diversion?

\begin{tabular}{|l|c|c|c|c|c|}
\hline \hline \multirow{2}{*}{ Model } & RTA-members & \multicolumn{4}{|c|}{ Non-RTA-members } \\
\hline Log real GDP p/c & Default & $\begin{array}{c}\text { Top 10 Export } \\
\text { Destination }\end{array}$ & $\begin{array}{c}\text { Top 5 Export } \\
\text { Destination }\end{array}$ & $\begin{array}{c}\text { Top 3 Export } \\
\text { Destination }\end{array}$ & $\begin{array}{c}\text { Top 1 Export } \\
\text { Destination }\end{array}$ \\
\cline { 2 - 6 } & $-0.248^{*}$ & 0.013 & -0.027 & -0.088 & -0.198 \\
\hline Log real GDP & $(0.12)$ & $(0.06)$ & $(0.07)$ & $(0.08)$ & $(0.13)$ \\
& 0.042 & 0.089 & 0.139 & 0.065 & 0.041 \\
\hline Log Trade/GDP & $(0.08)$ & $(0.06)$ & $(0.08)$ & $(0.07)$ & $(0.07)$ \\
\hline & -0.099 & 0.132 & 0.272 & 0.344 & 0.134 \\
\hline Log National Stocks/GDP & $(0.16)$ & $(0.13)$ & $(0.17)$ & $(0.23)$ & $(0.28)$ \\
\hline & 0.043 & $-0.120^{*}$ & $-0.120^{\circ}$ & -0.044 & 0.023 \\
\hline Exports to RTA partners/GDP & $(0.08)$ & $(0.06)$ & $(0.07)$ & $(0.07)$ & $(0.08)$ \\
\hline & $2.620^{* *}$ & -0.929 & -1.352 & -1.352 & -0.655 \\
\hline RTA-partner's log real GDP & $(0.79)$ & $(0.97)$ & $(1.10)$ & $(1.14)$ & $(1.42)$ \\
\hline & $-0.153^{* *}$ & 0.073 & 0.065 & 0.102 & -0.126 \\
\hline Number of Observations & $(0.06)$ & $(0.06)$ & $(0.07)$ & $(0.09)$ & $(0.18)$ \\
\hline \hline
\end{tabular}

Note: Each column is estimated via OLS; $(t-1, t+5)$ event window. Estimates in Column (1) show the baseline results from Table 1 for comparability, covering 82 developing and developed countries and 122 RTAs from 1988 to 2009. Columns (2) to (5) display results for stock market returns of countries that are not part of a new RTA. For these nonRTA members (at least one) RTA-member country constitutes an important export destination (Top 10, 5, 3 or 1). Event date defined as announcement of the start of negotiations of RTA or announcement of a successful conclusion of such an agreement. Coefficients with standard errors clustered at the country-level in parentheses. Coefficients significantly different from zero at [0.10] 0.05 (0.01) marked with [one circle] one (two) asterisk(s). Regressand: National Stock Market return in local currency, adjusted for MSCI movement (unless indicated otherwise). Time-fixed effects, intercepts and Goods/Goods\&Services dummy included but not reported. 
Appendix Table 1: Pooling Test for First Stage of Event Study

\begin{tabular}{|l|c|c|c|c|c|}
\hline Event window & $(\mathbf{t}-\mathbf{1}, \mathbf{t}+\mathbf{1})$ & $\mathbf{( t - 1 , \mathbf { t } + \mathbf { 3 } )}$ & $\mathbf{( t - 1 , \mathbf { t } + \mathbf { 5 } )}$ & $\mathbf{( t - 1 , \mathbf { t } + \mathbf { 7 } )}$ & $\mathbf{( t - 1 , \mathbf { t } + \mathbf { 1 0 } )}$ \\
\hline Event dummy & -0.038 & 0.175 & -0.192 & -0.175 & -0.128 \\
& $(0.18)$ & $(0.24)$ & $(0.24)$ & $(0.28)$ & $(0.33)$ \\
\hline
\end{tabular}

Note: The dependent variable is the average cumulative abnormal returns (in local currency) for the main sample of 1001 observations. The dummy variable event is one if the announcement marks the start of RTA negotiations and zero, if the announcement of a new trade agreement is made. Standard errors in brackets are computed using the cross. section standard deviation of the returns and account for variance inflation and clustering at the announcement day. Returns significantly different from zero at [0.10] 0.05 (0.01) marked with [one circle] one (two) asterisk(s).

\section{Appendix Table A2: Pooling Test for Second Stage of Event Study}

\begin{tabular}{|c|c|c|c|c|c|}
\hline Event window & $(t-1, t+1)$ & $(t-1, t+5)$ & $\overline{(t-1, t+10)}$ & $(t-1, t+15)$ & $(t-1, t+20)$ \\
\hline \multirow[t]{2}{*}{ Log real GDP p/c } & $-0.339 *$ & $-0.354^{*}$ & $-0.355^{*}$ & $-0.398 *$ & -0.340 \\
\hline & $(0.14)$ & $(0.14)$ & $(0.17)$ & $(0.18)$ & $(0.23)$ \\
\hline \multirow[t]{2}{*}{ Log real GDP p/c * Event } & $0.424^{\circ}$ & $0.406^{\circ}$ & 0.281 & 0.247 & 0.111 \\
\hline & $(0.22)$ & $(0.22)$ & $(0.25)$ & $(0.23)$ & $(0.25)$ \\
\hline \multirow[t]{2}{*}{ Log real GDP } & 0.067 & 0.003 & 0.045 & 0.028 & 0.078 \\
\hline & $(0.07)$ & $(0.06)$ & $(0.09)$ & $(0.11)$ & $(0.13)$ \\
\hline \multirow[t]{2}{*}{ Log real GDP * Event } & -0.109 & 0.028 & 0.004 & 0.130 & 0.179 \\
\hline & $(0.11)$ & $(0.12)$ & $(0.15)$ & $(0.17)$ & $(0.16)$ \\
\hline \multirow[t]{2}{*}{ Log Trade/GDP } & -0.049 & -0.058 & -0.132 & 0.076 & -0.012 \\
\hline & $(0.15)$ & $(0.16)$ & $(0.21)$ & $(0.27)$ & $(0.34)$ \\
\hline \multirow[t]{2}{*}{ Log Trade/GDP * Event } & -0.076 & 0.007 & 0.090 & 0.197 & 0.423 \\
\hline & $(0.21)$ & $(0.24)$ & $(0.29)$ & $(0.37)$ & $(0.44)$ \\
\hline \multirow[t]{2}{*}{ Log National Stocks/GDP } & 0.107 & 0.124 & 0.061 & -0.028 & -0.021 \\
\hline & $(0.08)$ & $(0.08)$ & $(0.11)$ & $(0.13)$ & $(0.16)$ \\
\hline Log National Stocks/GDP * & -0.139 & -0.142 & -0.057 & 0.092 & 0.003 \\
\hline Event & $(0.10)$ & $(0.13)$ & $(0.16)$ & $(0.18)$ & $(0.21)$ \\
\hline \multirow[t]{2}{*}{ Exports to RTA partners/GDP } & $1.574^{* *}$ & $1.723^{* *}$ & $2.570^{*}$ & $2.196^{\circ}$ & $2.978^{*}$ \\
\hline & $(0.60)$ & $(0.63)$ & $(1.02)$ & $(1.25)$ & $(1.32)$ \\
\hline Exports to RTA partners/GDP * & -0.100 & -0.904 & 0.165 & -0.047 & 1.257 \\
\hline Event & $(1.89)$ & $(2.19)$ & $(2.63)$ & $(3.00)$ & $(3.05)$ \\
\hline \multirow[t]{2}{*}{ RTA-partner's log real GDP } & $-0.103^{*}$ & $-0.122^{*}$ & -0.082 & -0.135 & $-0.193^{\circ}$ \\
\hline & $(0.05)$ & $(0.06)$ & $(0.08)$ & $(0.09)$ & $(0.11)$ \\
\hline RTA-partner's log real GDP * & 0.010 & 0.064 & -0.145 & -0.028 & 0.072 \\
\hline Event & $(0.10)$ & $(0.11)$ & $(0.15)$ & $(0.15)$ & $(0.17)$ \\
\hline
\end{tabular}

Note: Each column is estimated via OLS. Estimates based on 1001 observations, covering 82 developing and developed countries and 122 RTAs from 1988 to 2009. Event date defined as announcement of the start of negotiations of RTA or announcement of a successful conclusion of such an agreement. Coefficients with standard errors clustered at the country-level in parentheses. Coefficients significantly different from zero at [0.10] $0.05(0.01)$ marked with [one circle] one (two) asterisk(s). Regressand: National Stock Market return in local currency, beta-adjusted for MSCI movement. Dummy variable Event is one if the announcement marks the start of RTA negotiations and zero, if the announcement a new trade agreement is made. Time-fixed effects, intercepts and dummy variables for RTA-coverage and Event included but not reported. 
Appendix Table A3: Financial Crises and Extreme Stock Market Returns (in LC)

\begin{tabular}{|c|c|c|c|c|c|}
\hline Model & Default & $\begin{array}{c}\text { No financial } \\
\text { crises }\end{array}$ & $\begin{array}{c}\text { Trimmed } \\
\text { sample }(1 \%) \\
\end{array}$ & $\begin{array}{c}\text { Trimmed } \\
\text { sample }(2 \%)\end{array}$ & $\begin{array}{c}\text { Trimmed } \\
\text { sample }(5 \%)\end{array}$ \\
\hline \multirow[t]{2}{*}{ Log real GDP p/c } & $-0.248 *$ & $-0.282 * *$ & $-0.231 *$ & $-0.201 *$ & $-0.139^{\circ}$ \\
\hline & $(0.12)$ & $(0.10)$ & $(0.10)$ & $(0.10)$ & $(0.08)$ \\
\hline \multirow[t]{2}{*}{ Log real GDP } & 0.042 & 0.064 & 0.062 & 0.046 & 0.091 \\
\hline & $(0.08)$ & $(0.07)$ & $(0.08)$ & $(0.08)$ & $(0.06)$ \\
\hline \multirow[t]{2}{*}{ Log Trade/GDP } & -0.099 & -0.133 & -0.122 & -0.111 & 0.044 \\
\hline & $(0.16)$ & $(0.15)$ & $(0.17)$ & $(0.16)$ & $(0.12)$ \\
\hline \multirow[t]{2}{*}{ Log National Stocks/GDP } & 0.043 & 0.030 & 0.071 & 0.065 & -0.017 \\
\hline & $(0.08)$ & $(0.08)$ & $(0.08)$ & $(0.08)$ & $(0.06)$ \\
\hline \multirow[t]{2}{*}{ Exports to RTA partners/GDP } & $2.620 * *$ & $2.755^{* *}$ & $2.371 * *$ & $2.309 * *$ & $1.859 * *$ \\
\hline & $(0.79)$ & $(0.78)$ & $(0.80)$ & $(0.80)$ & $(0.68)$ \\
\hline \multirow[t]{2}{*}{ RTA-partner's log real GDP } & $-0.153 * *$ & $-0.183 * *$ & $-0.104^{\circ}$ & $-0.110 *$ & $-0.127 * *$ \\
\hline & $(0.06)$ & $(0.06)$ & $(0.06)$ & $(0.05)$ & $(0.05)$ \\
\hline Number of Observations & 1001 & 952 & 992 & 983 & 953 \\
\hline
\end{tabular}

Note: Each column is estimated via OLS; $(\mathrm{t}-1, \mathrm{t}+5)$ event window. Estimates in Column (1) show the baseline results from Table 1 for comparability, covering 82 developing and developed countries and 122 RTAs from 1988 to 2009. In Column (2), sample is restricted to observations with no major financial crisis (see endnote details). Columns (3), (4) and (5) report results for local returns, where top and bottom $0.5 \%, 1 \%$ and $2.5 \%$ is dropped, respectively. Event date defined as announcement of the start of negotiations of RTA or announcement of a successful conclusion of such an agreement. Coefficients with standard errors clustered at the country-level in parentheses. Coefficients significantly different from zero at [0.10] 0.05 (0.01) marked with [one circle] one (two) asterisk(s). Regressand: National Stock Market return in local currency, adjusted for MSCI movement. Time-fixed effects, intercepts and Goods/Goods\&Services dummy included but not reported.

\section{Appendix Table A4: Stock Market Returns in U.S. Dollar}

\begin{tabular}{|l|c|c|c|c|c|}
\hline \hline Event window & $(\mathbf{t}-\mathbf{1}, \mathbf{t}+\mathbf{1})$ & $\mathbf{( t - 1 , \mathbf { t } + \mathbf { 3 } )}$ & $\mathbf{( t - 1 , \mathbf { t } + \mathbf { 5 } )}$ & $\mathbf{( t - 1 , \mathbf { t } + \mathbf { 7 } )}$ & $\mathbf{( t - 1 , \mathbf { t } + \mathbf { 1 0 } )}$ \\
\hline Log real GDP p/c & -0.147 & $-0.205^{\circ}$ & $-0.322^{*}$ & $-0.326^{*}$ & -0.212 \\
& $(0.09)$ & $(0.12)$ & $(0.15)$ & $(0.16)$ & $(0.23)$ \\
\hline Log real GDP & -0.016 & 0.053 & 0.026 & 0.100 & 0.187 \\
\hline & $(0.06)$ & $(0.08)$ & $(0.10)$ & $(0.11)$ & $(0.15)$ \\
\hline Log Trade/GDP & $-0.257^{*}$ & $-0.363^{\circ}$ & $-0.491^{\circ}$ & -0.273 & -0.073 \\
\hline & $(0.12)$ & $(0.19)$ & $(0.27)$ & $(0.30)$ & $(0.30)$ \\
\hline Log National Stocks/GDP & $0.129^{*}$ & $0.163^{*}$ & 0.154 & 0.113 & 0.056 \\
\hline Exports to RTA partners/GDP & $(0.06)$ & $(0.08)$ & $(0.10)$ & $(0.11)$ & $(0.14)$ \\
\hline & $2.039^{* *}$ & $2.160^{*}$ & $2.726^{*}$ & $3.890^{* *}$ & $5.973^{* *}$ \\
\hline RTA-partner's log real GDP & $(0.74)$ & $(0.92)$ & $(1.28)$ & $(1.22)$ & $(1.28)$ \\
\hline \hline & $-0.131^{* *}$ & -0.070 & $-0.162^{*}$ & -0.051 & $-0.210^{\circ}$ \\
\hline
\end{tabular}

Note: Each column is estimated via OLS. Estimates based on 928 observations, covering 80 developing and developed countries and 122 RTAs from 1988 to 2009. Event date defined as announcement of the start of negotiations of RTA or announcement of a successful conclusion of such an agreement. Coefficients with standard errors clustered at countrylevel in parentheses. Coefficients significantly different from zero at [0.10] 0.05 (0.01) marked with [one circle] one (two) asterisk(s). Regressand: National Stock Market return in U.S. dollar, adjusted for MSCI movement. Time-fixed effects, intercepts and Goods/Goods\&Services dummy included but not reported. 
Appendix Table A5: Extra Variables on RTA-partner

\begin{tabular}{|c|c|c|c|c|c|}
\hline Model & Default & $\begin{array}{c}\text { RTA-partner } \\
\text { GDP p/c }\end{array}$ & $\begin{array}{c}\text { RTA-partner } \\
\text { Size }\end{array}$ & $\begin{array}{c}\text { Rel. Capital } \\
\text { Endowment }\end{array}$ & Similarity \\
\hline Event window & $(t-1, t+5)$ & $(t-1, t+5)$ & $(t-1, t+5)$ & $(t-1, t+5)$ & $(t-1, t+5)$ \\
\hline \multirow{2}{*}{ Log real GDP p/c } & $-0.248 *$ & $-0.255^{*}$ & $-0.272 *$ & $-0.238^{\circ}$ & $-0.248 *$ \\
\hline & $(0.12)$ & $(0.12)$ & $(0.12)$ & $(0.12)$ & $(0.12)$ \\
\hline \multirow[t]{2}{*}{ Log real GDP } & 0.042 & 0.046 & 0.072 & 0.046 & 0.056 \\
\hline & $(0.08)$ & $(0.08)$ & $(0.09)$ & $(0.08)$ & $(0.08)$ \\
\hline \multirow[t]{2}{*}{ Log Trade/GDP } & -0.099 & -0.091 & -0.074 & -0.099 & -0.120 \\
\hline & $(0.16)$ & $(0.16)$ & $(0.17)$ & $(0.16)$ & $(0.16)$ \\
\hline \multirow[t]{2}{*}{ Log National Stocks/GDP } & 0.043 & 0.046 & 0.035 & 0.040 & 0.043 \\
\hline & $(0.08)$ & $(0.08)$ & $(0.08)$ & $(0.08)$ & $(0.08)$ \\
\hline \multirow[t]{2}{*}{ Exports to RTA partners/GDP } & $2.620^{* *}$ & $2.756^{* *}$ & $2.802 * *$ & $2.681^{* *}$ & $2.655^{* *}$ \\
\hline & $(0.79)$ & $(0.84)$ & $(0.82)$ & $(0.81)$ & $(0.80)$ \\
\hline \multirow[t]{2}{*}{ RTA-partner's log real GDP } & $-0.153^{* *}$ & $-0.179 *$ & $-0.148 * *$ & $-0.158^{* *}$ & $-0.159 * *$ \\
\hline & $(0.06)$ & $(0.07)$ & $(0.05)$ & $(0.06)$ & $(0.06)$ \\
\hline \multirow[t]{2}{*}{ RTA-partner's log real GDP p/c } & & 0.074 & & & \\
\hline & & $(0.10)$ & & & \\
\hline \multirow[t]{2}{*}{ RTA-partner's log Population } & & & -0.084 & & \\
\hline & & & $(0.10)$ & & \\
\hline \multirow[t]{2}{*}{ Proxy relative capital endowment } & & & & -0.072 & \\
\hline & & & & $(0.10)$ & \\
\hline \multirow[t]{2}{*}{ Proxy similarity } & & & & & 0.062 \\
\hline & & & & & $(0.10)$ \\
\hline
\end{tabular}

Note: Each column is estimated via OLS. Estimates based on 1001 observations, covering 82 developing and developed countries and 122 RTAs from 1988 to 2009. Event date defined as announcement of the start of negotiations of RTA or announcement of a successful conclusion of such an agreement. Coefficients with standard errors clustered at countrylevel in parentheses. Coefficients significantly different from zero at [0.10] 0.05 (0.01) marked with [one circle] one (two) asterisk(s). Regressand: National Stock Market return in local currency, beta-adjusted for MSCI movement. Timefixed effects, intercepts and dummy variable RTA-coverage included but not reported. 


\begin{tabular}{|c|c|c|c|c|c|}
\hline Model & Default & Distance & $\begin{array}{c}\text { Number of } \\
\text { Listed Firms }\end{array}$ & $\begin{array}{l}\text { Corruption } \\
\text { Index }\end{array}$ & $\begin{array}{c}\text { Exports and } \\
\text { Imports to RTA }\end{array}$ \\
\hline Event window & $(t-1, t+5)$ & $(t-1, t+5)$ & $(t-1, t+5)$ & $(t-1, t+5)$ & $(t-1, t+5)$ \\
\hline \multirow[t]{2}{*}{$\overline{L o g}$ real GDP p/c } & $-0.248 *$ & $-0.255^{*}$ & $-0.225^{\circ}$ & $-0.443 * *$ & $-0.253^{*}$ \\
\hline & $(0.12)$ & $(0.12)$ & $(0.12)$ & $(0.13)$ & $(0.12)$ \\
\hline \multirow[t]{2}{*}{ Log real GDP } & 0.042 & 0.017 & -0.005 & 0.112 & 0.044 \\
\hline & $(0.08)$ & $(0.09)$ & $(0.10)$ & $(0.09)$ & $(0.08)$ \\
\hline \multirow[t]{2}{*}{ Log Trade/GDP } & -0.099 & -0.155 & -0.127 & -0.061 & -0.093 \\
\hline & $(0.16)$ & $(0.17)$ & $(0.17)$ & $(0.16)$ & $(0.17)$ \\
\hline \multirow[t]{2}{*}{ Log National Stocks/GDP } & 0.043 & 0.035 & 0.048 & -0.023 & 0.053 \\
\hline & $(0.08)$ & $(0.09)$ & $(0.09)$ & $(0.09)$ & $(0.09)$ \\
\hline \multirow[t]{2}{*}{ Exports to RTA partners/GDP } & $2.620 * *$ & $2.967 * *$ & $2.574^{* *}$ & $2.346^{* *}$ & \\
\hline & $(0.79)$ & $(0.88)$ & $(0.80)$ & $(0.80)$ & \\
\hline \multirow[t]{2}{*}{ RTA-partner's log real GDP } & $-0.153^{* *}$ & $-0.184^{* *}$ & $-0.145^{*}$ & $-0.151 *$ & $-0.162 *$ \\
\hline & $(0.06)$ & $(0.06)$ & $(0.06)$ & $(0.06)$ & $(0.06)$ \\
\hline \multirow[t]{2}{*}{ Log distance } & & 0.041 & & & \\
\hline & & $(0.12)$ & & & \\
\hline \multirow[t]{2}{*}{ Log Number of Listed Firms } & & & 0.042 & & \\
\hline & & & $(0.12)$ & & \\
\hline \multirow[t]{2}{*}{ Corruption Index (ICRG) } & & & & $0.279 * *$ & \\
\hline & & & & $(0.09)$ & \\
\hline Exports to and Imports from & & & & & $1.392^{*}$ \\
\hline RTA partners/GDP & & & & & $(0.058$ \\
\hline
\end{tabular}

Note: Each column is estimated via OLS. Estimates based on 1001 observations, covering 82 developing and developed countries and 122 RTAs from 1988 to 2009. Event date defined as announcement of the start of negotiations of RTA or announcement of a successful conclusion of such an agreement. Coefficients with standard errors clustered at countrylevel in parentheses. The variable Distance is measured as the (log) average distance to RTA-partners. The variables (log) Number of Listed Firms and the Corruption Index (ICRG) refer to country i. Coefficients significantly different from zero at [0.10] 0.05 (0.01) marked with [one circle] one (two) asterisk(s). Regressand: National Stock Market return in local currency, beta-adjusted for MSCI movement. Time-fixed effects, intercepts and dummy variable RTA-coverage included but not reported. 


\section{Online Appendix}

(Not Intended for Publication) 
Table OA1: Announcements on Regional Trade Agreements (RTAs), RTA-members, date, name, and other characteristics (1988 - 2009).

\begin{tabular}{|c|c|c|c|c|c|}
\hline Name of RTA & $\begin{array}{l}\text { Event date } \\
\text { (LexisNexis) }\end{array}$ & $\begin{array}{l}\text { Event } \\
\text { Type }\end{array}$ & "RTA-members in data set & Description of Announcement & $\begin{array}{l}\text { Signature } \\
\text { date (WTO) }\end{array}$ \\
\hline $\begin{array}{l}\text { Global System of Trade } \\
\text { Preferences among } \\
\text { Developing Countries (GSTP) }\end{array}$ & 13 Apr. 1988 & Deal & $\begin{array}{l}\text { Argentina, Chile, Peru, Sri } \\
\text { Lanka, India, Indonesia, } \\
\text { Malaysia, Philippines, } \\
\text { Singapore, Thailand }\end{array}$ & $\begin{array}{l}\text { Ministers of nearly } 50 \text { developing nations have } \\
\text { agreed in the "Belgrade Declaration" to grant one } \\
\text { another tariff concessions and trade preferences. }\end{array}$ & 13 Apr. 1988 \\
\hline ANZCERTA (Services) & 18 Aug. 1988 & Deal & Australia, New Zealand & $\begin{array}{l}\text { New Zealand's Prime Minister recognizes that the } \\
\text { world economy is increasingly characterized by } \\
\text { strong growth in trade in services [..] two countries } \\
\text { agreed to include services in its free trade } \\
\text { agreement. }\end{array}$ & 18 Aug. 1988 \\
\hline $\begin{array}{l}\text { European Economic Area } \\
\text { (EEA) }\end{array}$ & 19 Dec. 1989 & Start & $\begin{array}{l}\text { Austria, Denmark, France, } \\
\text { Finland, Germany, Greece, } \\
\text { Italy Netherlands, Norway, } \\
\text { Portugal, Spain, Sweden, } \\
\text { United Kingdom }\end{array}$ & $\begin{array}{l}\text { The } 19 \text { European Community and seven European } \\
\text { Free Trade Association nations agreed Tuesday to } \\
\text { begin talks early next year on closer economic } \\
\text { cooperation aimed at forging a so called European } \\
\text { Economic Space. }\end{array}$ & --- \\
\hline $\begin{array}{l}\text { North American Free Trade } \\
\text { Agreement (NAFTA) }\end{array}$ & 11 June 1990 & Start & Mexico, United States & $\begin{array}{l}\text { United States and Mexico agreed to begin work on a } \\
\text { free-trade accord [..] in a joint statement issued } \\
\text { Monday by the White House. }\end{array}$ & --- \\
\hline $\begin{array}{l}\text { Economic Cooperation } \\
\text { Organization (ECO) }\end{array}$ & 19 June 1990 & Deal & Pakistan, Turkey & $\begin{array}{l}\text { Pakistan, Iran and Turkey have agreed to enhance } \\
\text { their cooperation in economic, technical and other } \\
\text { fields in an extraordinary ministerial meeting of ECO } \\
\text { in Islamabad. }\end{array}$ & $\mathrm{N} / \mathrm{A}$ \\
\hline $\begin{array}{l}\text { Southern Common Market } \\
\text { (MERCOSUR) }\end{array}$ & $\begin{array}{l}6 \text { July } 1990 \text { / } \\
1 \text { Aug. } 1990\end{array}$ & Start & Argentina, Brazil & $\begin{array}{l}\text { Presidents of Argentina and Brazil signed a } \\
\text { statement "to establish a common market [..] which } \\
\text { must be formed by January 1,1995." }\end{array}$ & --- \\
\hline Chile - Mexico & 20 Sept. 1990 & Deal & Chile, Mexico & $\begin{array}{l}\text { Mexico and Chile will sign a FTA next month [... Mr. } \\
\text { Serra, Mexico's Secretary of Trade and Industry, and } \\
\text { Chilean Finance Minister Mr. Foxley announced the } \\
\text { deal. }\end{array}$ & 17 Apr. 1998 \\
\hline $\begin{array}{l}\text { North American Free Trade } \\
\text { Agreement (NAFTA) }\end{array}$ & 24 Sept. 1990 & Start & $\begin{array}{l}\text { Canada, Mexico, United } \\
\text { States }\end{array}$ & $\begin{array}{l}\text { Canadian government announced Monday it would } \\
\text { plunge into trade talks underway between the United } \\
\text { States and Mexico. }\end{array}$ & $\begin{array}{ll}-- \\
-1\end{array}$ \\
\hline $\begin{array}{l}\text { Southern Common Market } \\
\text { (MERCOSUR) }\end{array}$ & $\begin{array}{l}20 \text { March } \\
1991\end{array}$ & Deal & Argentina, Brazil & $\begin{array}{l}\text { Presidents of Brazil, Argentina, Uruguay and } \\
\text { Paraguay will meet Tuesday to sign a common } \\
\text { market treaty, Brazil's Foreign Ministry announced } \\
\text { Wednesday. }\end{array}$ & 29 Nov. 1991 \\
\hline
\end{tabular}




\begin{tabular}{|c|c|c|c|c|c|}
\hline EC (15) Enlargement & 31 July 1991 & Start & $\begin{array}{l}\text { Austria, Belgium, Denmark, } \\
\text { France, Germany, Greece, } \\
\text { Italy, Netherlands, Portugal, } \\
\text { Spain, United Kingdom }\end{array}$ & $\begin{array}{l}\text { European Commission recommended today that } \\
\text { Austria should become a member of the European } \\
\text { Community. This is the gist of the so-called "avis". }\end{array}$ & --- \\
\hline $\begin{array}{l}\text { ASEAN Free Trade Area } \\
\text { (AFTA) }\end{array}$ & 8 Oct. 1991 & Start & $\begin{array}{l}\text { Indonesia, Malaysia, } \\
\text { Philippines, Singapore, } \\
\text { Thailand }\end{array}$ & $\begin{array}{l}\text { Economic Ministers of the Association of Southeast } \\
\text { Asian Nations (ASEAN) on Tuesday announced } \\
\text { plans to establish a free trade area. }\end{array}$ & --- \\
\hline EFTA - Turkey & 17 Oct. 1991 & Deal & $\begin{array}{l}\text { Austria, Finland, Norway, } \\
\text { Sweden, Switzerland, Turkey }\end{array}$ & $\begin{array}{l}\text { Free trade negotiations between the EFTA countries } \\
\text { and Turkey were concluded on October } 17 \text { in } \\
\text { Geneva, when a FTA was initialed by representatives } \\
\text { of the two parties. }\end{array}$ & 10 Dec. 1991 \\
\hline $\begin{array}{l}\text { European Economic Area } \\
\text { (EEA) }\end{array}$ & 22 Oct. 1991 & Deal & $\begin{array}{l}\text { Austria, Belgium, Denmark, } \\
\text { France, Finland, Germany, } \\
\text { Greece, Italy Netherlands, } \\
\text { Norway, Portugal, Spain, } \\
\text { Sweden, Switzerland, United } \\
\text { Kingdom }\end{array}$ & $\begin{array}{l}\text { European Community }(\mathrm{EC}) \text { and the EFTA nations of } \\
\text { northern Europe agreed here early Tuesday to form } \\
\text { the world's largest common market. }\end{array}$ & 2 May 1992 \\
\hline $\begin{array}{l}\text { South Asian Preferential } \\
\text { Trade Arrangement (SAPTA) }\end{array}$ & 23 Dec. 1991 & Start & $\begin{array}{l}\text { Bangladesh, India, Pakistan, } \\
\text { Sri Lanka }\end{array}$ & $\begin{array}{l}\text { The sixth SAARC summit concluded [..] also agreed } \\
\text { to examine host Sri Lanka's proposal to set up a } \\
\text { "SAARC Preferential Trade Arrangement" by } 1997 .\end{array}$ & --- \\
\hline $\begin{array}{l}\text { ASEAN Free Trade Area } \\
\text { (AFTA) }\end{array}$ & 28 Jan. 1992 & Deal & $\begin{array}{l}\text { Indonesia, Malaysia, } \\
\text { Philippines, Singapore, } \\
\text { Thailand }\end{array}$ & $\begin{array}{l}\text { ASEAN economic ministers signed an agreement on } \\
\text { the common effective preferential tariff for the Asean } \\
\text { Free Trade Area (AFTA). }\end{array}$ & N/A \\
\hline EFTA - Israel & 16 July 1992 & Deal & $\begin{array}{l}\text { Austria, Finland, Israel, } \\
\text { Norway, Sweden, Switzerland }\end{array}$ & $\begin{array}{l}\text { Israel and the seven members of EFTA yesterday } \\
\text { reached a free trade agreement after } 13 \text { months of } \\
\text { negotiations. }\end{array}$ & $\begin{array}{l}17 \text { Sept. } \\
1992\end{array}$ \\
\hline EC (15) Enlargement & 31 July 1992 & Start & $\begin{array}{l}\text { Austria, Belgium, Denmark, } \\
\text { France, Germany, Greece, } \\
\text { Italy, Netherlands, Portugal, } \\
\text { Spain, Sweden, United } \\
\text { Kingdom }\end{array}$ & $\begin{array}{l}\text { European Commission gave the go-ahead today to } \\
\text { open formal negotiations to bring Sweden into the } \\
\text { European Community. }\end{array}$ & --- \\
\hline $\begin{array}{l}\text { North American Free Trade } \\
\text { Agreement (NAFTA) }\end{array}$ & 12. Aug. 1992 & Deal & $\begin{array}{l}\text { Canada, Mexico, United } \\
\text { States }\end{array}$ & $\begin{array}{l}\text { U.S. President Bush announced that the US, Canada } \\
\text { and Mexico have reached a free-trade agreement to } \\
\text { create the world's largest trading bloc. }\end{array}$ & 17 Dec. 1992 \\
\hline EC - Israel & 2 Oct. 1992 & Start & $\begin{array}{l}\text { Belgium, Denmark, France, } \\
\text { Germany, Greece, Israel, } \\
\text { Italy, Netherlands, Portugal, } \\
\text { Spain, United Kingdom }\end{array}$ & $\begin{array}{l}\text { European Commission President Delors told Foreign } \\
\text { Minister Peres on Friday that the EC would renew its } \\
\text { economic accord. }\end{array}$ & --- \\
\hline EC (15) Enlargement & 4 Nov. 1992 & Start & $\begin{array}{l}\text { Austria, Belgium, Denmark, } \\
\text { Finland, France, Germany, }\end{array}$ & $\begin{array}{l}\text { European Commission recommended on } \\
\text { Wednesday that the } 12 \text { EC states open membership }\end{array}$ & --- \\
\hline
\end{tabular}




\begin{tabular}{|c|c|c|c|c|c|}
\hline & & & $\begin{array}{l}\text { Greece, Italy, Netherlands, } \\
\text { Portugal, Spain, Sweden, } \\
\text { United Kingdom }\end{array}$ & talks with Finland. & \\
\hline $\begin{array}{l}\text { South Asian Preferential } \\
\text { Trade Arrangement (SAPTA) }\end{array}$ & 12 April 1993 & Deal & $\begin{array}{l}\text { Bangladesh, India, Pakistan, } \\
\text { Sri Lanka }\end{array}$ & $\begin{array}{l}\text { South Asian leaders signed an agreement to pave } \\
\text { the way for preferential trading schemes (SAPTA) } \\
\text { yesterday. }\end{array}$ & 11 April 1993 \\
\hline EC (15) Enlargement & 2 March 1994 & Deal & $\begin{array}{l}\text { Austria, Belgium, Denmark, } \\
\text { Finland, France, Germany, } \\
\text { Greece, Ireland, Italy, } \\
\text { Netherlands, Portugal, Spain, } \\
\text { Sweden, United Kingdom }\end{array}$ & $\begin{array}{l}\text { Sweden, Finland and Austria agreed terms to join the } \\
\text { European Union after five days and three nights of } \\
\text { arduous talks. }\end{array}$ & $\begin{array}{l}24 \text { June } \\
1994\end{array}$ \\
\hline EC - South Africa & 10 Oct. 1994 & Start & $\begin{array}{l}\text { Belgium, Denmark, France, } \\
\text { Germany, Greece, Ireland, } \\
\text { Italy, Netherlands, Portugal, } \\
\text { Spain, United Kingdom }\end{array}$ & $\begin{array}{l}\text { EU and South Africa signed a co-operation } \\
\text { agreement [..] laying the groundwork for the } \\
\text { negotiation of a formal trade agreement. }\end{array}$ & $\begin{array}{ll}-- \\
\end{array}$ \\
\hline EC - Egypt & 3 Nov. 1994 & Start & $\begin{array}{l}\text { Belgium, Denmark, Egypt, } \\
\text { France, Germany, Greece, } \\
\text { Ireland, Italy, Netherlands, } \\
\text { Portugal, Spain, United } \\
\text { Kingdom }\end{array}$ & $\begin{array}{l}\text { European Commission stepped forward with a } \\
\text { recommendation for a Council Decision authorizing } \\
\text { the EU's executive agency to negotiate a Euro- } \\
\text { Mediterranean Association Agreement with Egypt. }\end{array}$ & $\begin{array}{ll}-- \\
\end{array}$ \\
\hline Canada - Israel & 23 Nov. 1994 & Start & Canada, Israel & $\begin{array}{l}\text { Canada and Israel are to negotiate a FTA, leaders of } \\
\text { the two countries announced Wednesday. }\end{array}$ & --- \\
\hline EC - Turkey & 6 March 1995 & Deal & $\begin{array}{l}\text { Austria, Belgium, Denmark, } \\
\text { Finland, France, Germany, } \\
\text { Greece, Ireland, Italy, } \\
\text { Netherlands, Portugal, Spain, } \\
\text { Sweden, Turkey, United } \\
\text { Kingdom }\end{array}$ & $\begin{array}{l}\text { EU concludes long-awaited customs union with } \\
\text { Turkey [..] a move the EU hopes will strengthen } \\
\text { Turkey's ties to the West. }\end{array}$ & $\begin{array}{l}6 \text { March } \\
1995\end{array}$ \\
\hline EC - Jordan & 12 June 1995 & Start & $\begin{array}{l}\text { Austria, Belgium, Denmark, } \\
\text { Finland, France, Germany, } \\
\text { Greece, Ireland, Italy, Jordan, } \\
\text { Netherlands, Portugal, Spain, } \\
\text { Sweden, United Kingdom }\end{array}$ & $\begin{array}{l}\text { EU Foreign Ministers approved a negotiating } \\
\text { mandate authorizing the EC to begin talks on an } \\
\text { Association Agreement with Jordan. }\end{array}$ & --- \\
\hline EC - Israel & 18 July 1995 & Deal & $\begin{array}{l}\text { Austria, Belgium, Denmark, } \\
\text { Finland, France, Germany, } \\
\text { Greece, Ireland, Israel, Italy, } \\
\text { Netherlands, Portugal, Spain, } \\
\text { Sweden, United Kingdom }\end{array}$ & $\begin{array}{l}\text { EU and Israel have reached a new trade agreement } \\
\text { eliminating most remaining tariffs [..] the Foreign } \\
\text { Ministry announced Tuesday. }\end{array}$ & 20 Nov. 1995 \\
\hline EC - Morocco & 15 Nov. 1995 & Deal & $\begin{array}{l}\text { Austria, Belgium, Denmark, } \\
\text { Finland, France, Germany, }\end{array}$ & $\begin{array}{l}\text { The EU and Morocco initialed an Association } \\
\text { Agreement on November } 15 \text { [..] replaces the }\end{array}$ & 26 Feb. 1996 \\
\hline
\end{tabular}




\begin{tabular}{|c|c|c|c|c|c|}
\hline & & & $\begin{array}{l}\text { Greece, Ireland, Italy, } \\
\text { Morocco, Netherlands, } \\
\text { Portugal, Spain, Sweden, } \\
\text { United Kingdom }\end{array}$ & Cooperation Agreement of 1976. & \\
\hline EC - Lebanon & 28 Nov. 1995 & Start & $\begin{array}{l}\text { Austria, Belgium, Denmark, } \\
\text { Finland, France, Germany, } \\
\text { Greece, Ireland, Italy, } \\
\text { Lebanon, Luxembourg, } \\
\text { Netherlands, Portugal, Spain, } \\
\text { Sweden, United Kingdom }\end{array}$ & $\begin{array}{l}\text { The European Union and its neighbors from the } \\
\text { Mideast and North Africa pledged Tuesday to lift } \\
\text { trade barriers and foster private investment across } \\
\text { the Mediterranean in pursuit of a free-trade area by } \\
2010 \text {. }\end{array}$ & --- \\
\hline $\begin{array}{l}\text { EFTA - Egypt / EFTA - } \\
\text { Morocco / EFTA - Tunisia }\end{array}$ & 8 Dec. 1995 & Start & $\begin{array}{l}\text { Iceland, Norway, Switzerland; } \\
\text { Egypt, Morocco, Tunisia. }\end{array}$ & $\begin{array}{l}\text { EFTA Ministers during their meeting in Zermatt on } \\
\text { December } 8 \text { [..] Ministers from Egypt, Morocco and } \\
\text { Tunisia signed Declarations on cooperation with the } \\
\text { EFTA states, which may eventually lead to full } \\
\text { Agreements. }\end{array}$ & --- \\
\hline Canada - Chile & 29 Dec. 1995 & Start & Canada, Chile & $\begin{array}{l}\text { Work will begin by mid-January on what is being } \\
\text { called an interim bilateral trade agreement with Chile, } \\
\text { Canadian Trade Minister Roy said. }\end{array}$ & --- \\
\hline Turkey - Israel & $\begin{array}{l}12 \text { March } \\
1996\end{array}$ & Deal & Israel, Turkey & $\begin{array}{l}\text { Turkish President Demirel is in Israel to sign bilateral } \\
\text { trade agreement with Israel. }\end{array}$ & $\begin{array}{l}14 \text { March } \\
1996\end{array}$ \\
\hline EC - Mexico & 13 May 1996 & Start & $\begin{array}{l}\text { Austria, Belgium, Denmark, } \\
\text { Finland, France, Germany, } \\
\text { Greece, Ireland, Italy, Mexico, } \\
\text { Netherlands, Portugal, Spain, } \\
\text { Sweden, United Kingdom }\end{array}$ & $\begin{array}{l}\text { European Union foreign ministers on Monday cleared } \\
\text { up a dispute that has long delayed the start of free- } \\
\text { trade negotiations with Mexico. }\end{array}$ & --- \\
\hline Canada - Israel & 22 July 1996 & Deal & Canada, Israel & $\begin{array}{l}\text { Israel and Canada are to sign a free-trade agreement } \\
\text { in Canada on July } 31 \text {, a spokesman for Israel's } \\
\text { Ministry of Industry and Trade said yesterday in } \\
\text { Jerusalem. }\end{array}$ & 31 July 1996 \\
\hline Canada - Chile & 14 Nov. 1996 & Deal & Canada, Chile & $\begin{array}{l}\text { Canada and Chile have reached a FTA, Canada's } \\
\text { Minister for international trade, Mr. Eggleton, } \\
\text { announced today. }\end{array}$ & 5 Dec. 1996 \\
\hline Israel - Mexico & 18 Feb. 1997 & Start & Israel, Mexico & $\begin{array}{l}\text { Israel and Mexico have agreed to negotiate a FTA [..] } \\
\text { spokesman of Israeli Trade Minister said yesterday. }\end{array}$ & --- \\
\hline $\begin{array}{l}\text { Pan-Arab Free Trade Area } \\
\text { (PAFTA) }\end{array}$ & 19 Feb. 1997 & Start & $\begin{array}{l}\text { Egypt, Jordan, Lebanon, } \\
\text { Morocco, Oman, Saudi } \\
\text { Arabia, Tunisia }\end{array}$ & $\begin{array}{l}\text { Economy and finance ministers from the } 22 \text { member } \\
\text { Arab League began talks in Cairo which will focus on } \\
\text { long-awaited plans to create an Arab common } \\
\text { market and a joint free-trade zone. }\end{array}$ & --- \\
\hline
\end{tabular}




\begin{tabular}{|c|c|c|c|c|c|}
\hline EC - Jordan & 16 April 1997 & Deal & $\begin{array}{l}\text { Austria, Belgium, Denmark, } \\
\text { Finland, France, Germany, } \\
\text { Greece, Ireland, Italy, } \\
\text { Luxembourg, Jordan, } \\
\text { Netherlands, Portugal, Spain, } \\
\text { Sweden, United Kingdom }\end{array}$ & $\begin{array}{l}\text { EU and Jordanian officials got together in the } \\
\text { Maltese capital of Valetta on April 16, to put their } \\
\text { initials to an Association Agreement aimed at } \\
\text { creating free trade in non-agricultural products. }\end{array}$ & 24 Nov. 1997 \\
\hline EFTA - Morocco & 11 June 1997 & Deal & $\begin{array}{l}\text { Iceland, Morocco, Norway, } \\
\text { Switzerland }\end{array}$ & $\begin{array}{l}\text { A Moroccan [Ministry of] Foreign Affairs statement } \\
\text { says the agreement with EFTA will be officially } \\
\text { signed in Geneva on June } 19^{\text {th }} \text {. }\end{array}$ & $\begin{array}{l}19 \text { June } \\
1997\end{array}$ \\
\hline EC (25) Enlargement & 16 July 1997 & Start & $\begin{array}{l}\text { Austria, Belgium, Cyprus, } \\
\text { Czech Republic, Denmark, } \\
\text { Estonia, Finland, France, } \\
\text { Germany, Greece, Hungary, } \\
\text { Ireland, Italy, Luxembourg, } \\
\text { Netherlands, Poland, } \\
\text { Portugal, Slovenia, Spain, } \\
\text { Sweden, United Kingdom }\end{array}$ & $\begin{array}{l}\text { EU Commission confirmed on Wednesday that it } \\
\text { would recommend [..] the Czech Republic, Estonia, } \\
\text { Hungary, Poland and Slovenia plus Cyprus [..] to } \\
\text { begin accession negotiations. }\end{array}$ & --- \\
\hline EFTA - Canada & 4 Dec. 1997 & Start & $\begin{array}{l}\text { Canada, Iceland, Norway, } \\
\text { Switzerland }\end{array}$ & $\begin{array}{l}\text { An initial meeting between EFTA and Canada, to } \\
\text { pave the way for a full FTA, will take place next year } \\
\text { [... Swiss Economy minister Mr. Delamurax said } \\
\text { Thursday. }\end{array}$ & --- \\
\hline $\begin{array}{l}\text { Pan-Arab Free Trade Area } \\
\text { (PAFTA) }\end{array}$ & 31 Dec. 1997 & Deal & $\begin{array}{l}\text { Egypt, Jordan, Lebanon, } \\
\text { Morocco, Oman, Saudi Arabia }\end{array}$ & $\begin{array}{l}\text { Arab League launched a regional free trade program } \\
\text { on Wednesday, a step that could lead to the creation } \\
\text { of an Arab common market. }\end{array}$ & 19 Feb. 1997 \\
\hline EC - Chile & 22 July 1998 & Start & $\begin{array}{l}\text { Austria, Belgium, Chile, } \\
\text { Denmark, Finland, France, } \\
\text { Germany, Greece, Ireland, } \\
\text { Italy, Luxembourg, } \\
\text { Netherlands, Portugal, Spain, } \\
\text { Sweden, United Kingdom }\end{array}$ & $\begin{array}{l}\text { European Commission yesterday took the first step } \\
\text { toward negotiating a free-trade arrangement with } \\
\text { Chile. }\end{array}$ & --- \\
\hline South Korea - Chile & 16 Nov. 1998 & Start & Chile, South Korea & $\begin{array}{l}\text { Korean President Dae-jung and Chilean President } \\
\text { Frei agreed here Tuesday to start negotiations on a } \\
\text { FTA between their two countries. }\end{array}$ & --- \\
\hline Egypt - Turkey & 7 Dec. 1998 & Start & Egypt, Turkey & $\begin{array}{l}\text { On Sunday, Egyptian President Mubarak urged } \\
\text { closer economic cooperation in the region [..] Turkey } \\
\text { and Egypt are aiming for a FTA. }\end{array}$ & --- \\
\hline India - Sri Lanka & 28 Dec. 1998 & Deal & India, Sri Lanka & $\begin{array}{l}\text { India and Sri Lanka signed a free-trade agreement } \\
\text { Monday that will eliminate customs tariffs between } \\
\text { the countries over several years. }\end{array}$ & 28 Dec. 1998 \\
\hline
\end{tabular}




\begin{tabular}{|c|c|c|c|c|c|}
\hline EC - South Africa & $\begin{array}{l}\text { 24 March } \\
1999\end{array}$ & Deal & $\begin{array}{l}\text { Austria, Belgium, Denmark, } \\
\text { Finland, France, Germany, } \\
\text { Greece, Ireland, Italy, } \\
\text { Luxembourg, Netherlands, } \\
\text { Portugal, South Africa, Spain, } \\
\text { Sweden, United Kingdom }\end{array}$ & $\begin{array}{l}\text { EU wrapped up four years of arduous negotiations by } \\
\text { agreeing the terms of a wide-ranging free-trade deal } \\
\text { with South Africa, German Foreign Minister Fischer } \\
\text { said Wednesday. }\end{array}$ & 11 Oct. 1999 \\
\hline EFTA - Mexico & 7 June 1999 & Start & $\begin{array}{l}\text { Iceland, Mexico, Norway, } \\
\text { Switzerland }\end{array}$ & $\begin{array}{l}\text { EFTA held its Spring Ministerial meeting in } \\
\text { Lillehammer, Norway [..] agreed to propose to } \\
\text { Mexico to start exploring the basis for a FTA. }\end{array}$ & --- \\
\hline New Zealand - Singapore & 13 Sept. 1999 & Start & New Zealand, Singapore & $\begin{array}{l}\text { Singapore and New Zealand took the lead in opening } \\
\text { up their economies when their two leaders agreed to } \\
\text { start negotiations on a FTA. }\end{array}$ & --- \\
\hline $\begin{array}{l}\text { EC (25) Enlargement / EC (27) } \\
\text { Enlargement }\end{array}$ & 13 Oct. 1999 & Start & $\begin{array}{l}\text { Austria, Belgium, Cyprus, } \\
\text { Czech Republic, Denmark, } \\
\text { Estonia, Finland, France, } \\
\text { Germany, Greece, Hungary, } \\
\text { Ireland, Italy, Luxembourg, } \\
\text { Malta, Netherlands, Poland, } \\
\text { Portugal, Romania, Slovenia, } \\
\text { Slovak Republic, Spain, } \\
\text { Sweden, United Kingdom }\end{array}$ & $\begin{array}{l}\text { European Commission President Prodi } \\
\text { recommended today that negotiations begin with } \\
\text { Bulgaria, Latvia, Lithuania, Malta, Romania and } \\
\text { Slovakia [..] should be added to the list of next year's } \\
\text { enlargement. }\end{array}$ & --- \\
\hline EC - Mexico & 24 Nov. 1999 & Deal & $\begin{array}{l}\text { Austria, Belgium, Denmark, } \\
\text { Finland, France, Germany, } \\
\text { Greece, Ireland, Italy, } \\
\text { Luxembourg, Mexico, } \\
\text { Netherlands, Portugal, Spain, } \\
\text { Sweden, United Kingdom }\end{array}$ & $\begin{array}{l}\text { European Union and Mexico wrapped up } 16 \text { months } \\
\text { of negotiations with an accord Wednesday on } \\
\text { establishing a free-trade pact, the EU's trade } \\
\text { commissioner said. }\end{array}$ & 8 Dec. 1997 \\
\hline Canada - Costa Rica & 31 Jan. 2000 & Start & Canada, Costa Rica & $\begin{array}{l}\text { Canada and Costa Rica have agreed to start } \\
\text { negotiations for a bilateral free trade agreement, the } \\
\text { leaders of the two countries announced Monday. }\end{array}$ & --- \\
\hline Israel - Mexico & 15 Feb. 2000 & Deal & Israel, Mexico & $\begin{array}{l}\text { Mexico and Israel have completed negotiations for a } \\
\text { free trade agreement, the Commerce Ministry said } \\
\text { on Monday. }\end{array}$ & 10 April 2000 \\
\hline $\begin{array}{l}\text { Asian Pacific Trade } \\
\text { Agreement (APTA) - } \\
\text { Accession of China }\end{array}$ & 7 April 2000 & Deal & $\begin{array}{l}\text { Bangladesh, China, India, } \\
\text { South Korea, Sri Lanka }\end{array}$ & $\begin{array}{l}\text { China has joined the United Nations' "Bangkok } \\
\text { Agreement" on trade, bringing the total membership } \\
\text { of the Asian preferential trading framework to six, the } \\
\text { UN said Friday. }\end{array}$ & 21 April 2001 \\
\hline EC - Croatia & 24 May 2000 & Start & $\begin{array}{l}\text { Austria, Belgium, Croatia, } \\
\text { Denmark, Finland, France, } \\
\text { Germany, Greece, Ireland, }\end{array}$ & $\begin{array}{l}\text { European Commission recommended closer ties with } \\
\text { Croatia as recognition for reforms underway there [..] } \\
\text { proposal authorizing the start of negotiations for a }\end{array}$ & --- \\
\hline
\end{tabular}




\begin{tabular}{|c|c|c|c|c|c|}
\hline & & & $\begin{array}{l}\text { Italy, Luxembourg, } \\
\text { Netherlands, Portugal, Spain, } \\
\text { Sweden, United Kingdom }\end{array}$ & $\begin{array}{l}\text { Stabilization and Association Agreement between the } \\
\text { EU and Croatia. }\end{array}$ & \\
\hline US - Jordan & 6 June 2000 & Start & Jordan, United States & $\begin{array}{l}\text { U.S. and Jordan decided to open bilateral } \\
\text { negotiations on a FTA, White House spokesman Mr. } \\
\text { Crowley announced Tuesday. }\end{array}$ & --- \\
\hline EFTA - Croatia & 20 June 2000 & Start & $\begin{array}{l}\text { Croatia, Iceland, Norway, } \\
\text { Switzerland }\end{array}$ & $\begin{array}{l}\text { EFTA and Croatia signed a declaration on } \\
\text { cooperation in Zurich on Monday [19th June], the } \\
\text { Croatian Economy Ministry said in a statement on } \\
\text { Tuesday. }\end{array}$ & $\begin{array}{ll}-- \\
\end{array}$ \\
\hline Pakistan - Sri Lanka & 31 July 2000 & Start & Pakistan, Sri Lanka & $\begin{array}{l}\text { Sri Lanka and Pakistan have initiated a dialogue to } \\
\text { work-out a FTA between the two countries, said } \\
\text { Pakistan's High Commissioner. }\end{array}$ & --- \\
\hline New Zealand - Singapore & 18 Aug. 2000 & Deal & New Zealand, Singapore & $\begin{array}{l}\text { Singapore and New Zealand have concluded } \\
\text { negotiations for a bilateral FTA expected to be } \\
\text { signed next month, the Singapore government said } \\
\text { Friday. }\end{array}$ & 24 Nov. 2000 \\
\hline US - Jordan & 19 Oct. 2000 & Deal & Jordan, United States & $\begin{array}{l}\text { Jordanian Prime Minister announced Thursday that } \\
\text { Jordan and the U.S. will sign on October, } 24,2000 .\end{array}$ & 24 Oct. 2000 \\
\hline Japan - Singapore & 23 Oct. 2000 & Start & Japan, Singapore & $\begin{array}{l}\text { Japanese and Singapore Prime Ministers announced } \\
\text { that their countries would launch negotiations on a } \\
\text { bilateral free trade agreement. }\end{array}$ & $\begin{array}{ll}-- \\
\end{array}$ \\
\hline EFTA - Mexico & 6 Nov. 2000 & Deal & $\begin{array}{l}\text { Iceland, Mexico, Norway, } \\
\text { Switzerland }\end{array}$ & $\begin{array}{l}\text { Mexico and EFTA have concluded their talks on a } \\
\text { FTA that will come into force next July, the Swiss } \\
\text { government said Monday. }\end{array}$ & 27 Nov. 2000 \\
\hline Singapore - Australia & 15 Nov. 2000 & Start & Australia, Singapore & $\begin{array}{l}\text { Singapore's and Australia's Prime Minister } \\
\text { announced Wednesday to start negotiations for a } \\
\text { bilateral FTA with the aim of concluding the pact } \\
\text { within a year. }\end{array}$ & --- \\
\hline US - Singapore & 16 Nov. 2000 & Start & Singapore, US & $\begin{array}{l}\text { Singapore's Prime Minister and the U.S. President } \\
\text { have agreed to start negotiations on a FTA said a } \\
\text { statement published here Thursday by the Singapore } \\
\text { government. }\end{array}$ & --- \\
\hline EFTA - Chile & 20 Nov. 2000 & Start & $\begin{array}{l}\text { Chile, Iceland, Norway, } \\
\text { Switzerland }\end{array}$ & $\begin{array}{l}\text { Chilean Foreign Minister Alvear told reporters that } \\
\text { Chile and EFTA had discussed the country's interest } \\
\text { in reaching an agreement. }\end{array}$ & --- \\
\hline ASEAN - China & 23 Nov. 2000 & Start & $\begin{array}{l}\text { China, Indonesia, Malaysia, } \\
\text { Philippines, Singapore, } \\
\text { Thailand }\end{array}$ & $\begin{array}{l}\text { Ministers from the } 10-\text { member ASEAN backed in } \\
\text { principle a Chinese proposal to set up a common } \\
\text { free trade zone but acknowledged the idea was still } \\
\text { at an early stage. }\end{array}$ & --- \\
\hline
\end{tabular}




\begin{tabular}{|c|c|c|c|c|c|}
\hline US - Chile & 30 Nov. 2000 & Start & Chile, United States & $\begin{array}{l}\text { United States and Chile have agreed to start } \\
\text { negotiations on a comprehensive bilateral FTA [..] } \\
\text { released today by the White House. }\end{array}$ & --- \\
\hline EC-Egypt & 26 Jan. 2001 & Deal & $\begin{array}{l}\text { Austria, Belgium, Denmark, } \\
\text { Egypt, Finland, France, } \\
\text { Germany, Greece, Ireland, } \\
\text { Italy, Luxembourg, } \\
\text { Netherlands, Portugal, Spain, } \\
\text { Sweden, United Kingdom }\end{array}$ & $\begin{array}{l}\text { Egypt and the European Commission initialed Friday } \\
\text { an association agreement that has been under } \\
\text { negotiation for more than five years. }\end{array}$ & $\begin{array}{l}25 \text { June } \\
2001\end{array}$ \\
\hline EFTA - Singapore & 9 Feb. 2001 & Start & $\begin{array}{l}\text { Iceland, Norway, Singapore, } \\
\text { Switzerland }\end{array}$ & $\begin{array}{l}\text { Switzerland's Economics Minister and Singapore's } \\
\text { top trade official were on Friday to announce the start } \\
\text { of talks toward a possible FTA. }\end{array}$ & --- \\
\hline EFTA - Croatia & 23 Feb. 2001 & Deal & $\begin{array}{l}\text { Croatia, Iceland, Norway, } \\
\text { Switzerland }\end{array}$ & $\begin{array}{l}\text { Croatia and EFTA have wrapped up negotiations } \\
\text { which began in Zagreb last October and initialed a } \\
\text { FTA the Croatian Economy Ministry said in a } \\
\text { statement on Friday. }\end{array}$ & $\begin{array}{l}21 \text { June } \\
2001\end{array}$ \\
\hline Thailand - Australia & 6 April 2001 & Start & Australia, Thailand & $\begin{array}{l}\text { Australia is pursuing a two-way FTA with Thailand } \\
\text { and will push for similar pacts with countries across } \\
\text { eastern Asia, Trade Minister Vaile said Friday. }\end{array}$ & --- \\
\hline Canada - Costa Rica & 23 April 2001 & Deal & Canada, Costa Rica & $\begin{array}{l}\text { Canada and Costa Rica signed a free-trade treaty on } \\
\text { Monday that could prove a model for a planned } \\
\text { Americas-wide pact. }\end{array}$ & 23 April 2001 \\
\hline EC - Croatia & 14 May 2001 & Deal & $\begin{array}{l}\text { Austria, Belgium, Croatia, } \\
\text { Denmark, Finland, France, } \\
\text { Germany, Greece, Ireland, } \\
\text { Italy, Luxembourg, } \\
\text { Netherlands, Portugal, Spain, } \\
\text { Sweden, United Kingdom }\end{array}$ & $\begin{array}{l}\text { EU External Relations Commissioner Patten and } \\
\text { Croatian Foreign Minister Picula signed the pact at } \\
\text { the end of a six- month negotiation process. }\end{array}$ & 29 Oct. 2001 \\
\hline EFTA - Jordan & 24 May 2001 & Deal & $\begin{array}{l}\text { Iceland, Jordan, Norway, } \\
\text { Switzerland }\end{array}$ & $\begin{array}{l}\text { A FTA will reportedly be signed between the EFTA } \\
\text { and Jordan next month [...] Officials from Jordan and } \\
\text { the four EFTA countries. }\end{array}$ & $\begin{array}{l}21 \text { June } \\
2001\end{array}$ \\
\hline Japan - Mexico & 5 June 2001 & Start & Japan, Mexico & $\begin{array}{l}\text { Mexican President Fox and Japanese Prime Minister } \\
\text { Koizumi agreed Tuesday to consider a bilateral free } \\
\text { trade agreement. }\end{array}$ & --- \\
\hline $\begin{array}{l}\text { European Free Trade } \\
\text { Association (EFTA - Services) }\end{array}$ & 21 June 2001 & Deal & Iceland, Norway, Switzerland & $\begin{array}{l}\text { The four EFTA countries have signed an updated } \\
\text { version of its founding convention, which EFTA } \\
\text { officials said would bring them into line with the } 1994 \\
\text { accord with the EU that established the European } \\
\text { Economic Area (EEA). }\end{array}$ & $\begin{array}{l}21 \text { June } \\
2001\end{array}$ \\
\hline
\end{tabular}




\begin{tabular}{|c|c|c|c|c|c|}
\hline Japan - Singapore & 12 Oct. 2001 & Deal & Japan, Singapore & $\begin{array}{l}\text { Singapore and Japan have reached basic agreement } \\
\text { to launch a bilateral FTA which they expect to sign by } \\
\text { the end of the year, a joint statement said Friday. }\end{array}$ & 13 Jan. 2002 \\
\hline $\begin{array}{l}\text { Southern African Customs } \\
\text { Union (SACU) }\end{array}$ & 26 Oct. 2001 & Deal & Namibia, South Africa & $\begin{array}{l}\text { The agreement between South Africa, Botswana, } \\
\text { Lesotho, Namibia and Swaziland was finalized on } \\
\text { Friday. }\end{array}$ & 21 Oct. 2002 \\
\hline EC - Lebanon & 19 Nov. 2001 & Deal & $\begin{array}{l}\text { Austria, Belgium, Denmark, } \\
\text { Finland, France, Germany, } \\
\text { Greece, Ireland, Italy, } \\
\text { Lebanon, Luxembourg, } \\
\text { Netherlands, Portugal, Spain, } \\
\text { Sweden, United Kingdom }\end{array}$ & $\begin{array}{l}\text { European Commission President Prodi said here } \\
\text { Monday that Lebanon and the European Union (EU) } \\
\text { will sign a partnership agreement within two weeks in } \\
\text { Brussels. }\end{array}$ & $\begin{array}{l}17 \text { June } \\
2002\end{array}$ \\
\hline EFTA - Singapore & 27 Nov. 2001 & Deal & $\begin{array}{l}\text { Iceland, Norway, Singapore, } \\
\text { Switzerland }\end{array}$ & $\begin{array}{l}\text { Singapore has completed a FTA with EFTA, an } \\
\text { official said Tuesday [..] likely be signed next year } \\
\text { after some legalities are finalized. }\end{array}$ & $\begin{array}{l}26 \text { June } \\
2002\end{array}$ \\
\hline Turkey - Croatia & 30 Nov. 2001 & Deal & Croatia, Turkey & $\begin{array}{l}\text { Croatia and Turkey initialed a FTA in Ankara, the } \\
\text { Croatian Economy Ministry said in a statement. }\end{array}$ & $\begin{array}{l}13 \text { March } \\
2002\end{array}$ \\
\hline China - Hong Kong & 19 Dec. 2001 & Start & China, Hong Kong & $\begin{array}{l}\text { China has pledged support for a proposed FTA with } \\
\text { Hong Kong, the territory's leader said on } \\
\text { Wednesday. }\end{array}$ & --- \\
\hline $\begin{array}{l}\text { Gulf Cooperation Council } \\
\text { (GCC) }\end{array}$ & 31 Dec. 2001 & Deal & $\begin{array}{l}\text { Bahrain, Kuwait, Oman, Saudi } \\
\text { Arabia }\end{array}$ & $\begin{array}{l}\text { Leaders of the six-nation Gulf Cooperation Council } \\
\text { signed an agreement paving the way for economic } \\
\text { union with goals of joint customs tariffs in } 2003 \text {. }\end{array}$ & 31 Dec. 2001 \\
\hline US - Morocco & 23 April 2002 & Start & Morocco, United States & $\begin{array}{l}\text { President Bush yesterday proposed that the U.S. and } \\
\text { Morocco enter into a FTA [..] following a meeting in } \\
\text { Washington with Morocco's King Mohammed. }\end{array}$ & --- \\
\hline EC - Chile & 26 April 2002 & Deal & $\begin{array}{l}\text { Austria, Belgium, Chile, } \\
\text { Denmark, Finland, France, } \\
\text { Germany, Greece, Ireland, } \\
\text { Italy, Luxembourg, } \\
\text { Netherlands, Portugal, Spain, } \\
\text { Sweden, United Kingdom }\end{array}$ & $\begin{array}{l}\text { EU and Chile reached a landmark free trade } \\
\text { agreement on Friday after more than two years of } \\
\text { talks. }\end{array}$ & 28 Nov. 2002 \\
\hline Panama - Taiwan & 9 Aug. 2002 & Start & Panama, Taiwan & $\begin{array}{l}\text { Taiwan's Premier Yu [..] an official visit to Panama } \\
\text { Friday, set to sign a statement of intent to forge a } \\
\text { deal for free trade with this Central American country } \\
\text { by late } 2003 \text {. }\end{array}$ & $\begin{array}{ll}-- \\
--\end{array}$ \\
\hline
\end{tabular}




\begin{tabular}{|c|c|c|c|c|c|}
\hline $\begin{array}{l}\text { Central European Free Trade } \\
\text { Agreement (CEFTA) - } \\
\text { Accession of Croatia }\end{array}$ & 16 Sept. 2002 & Deal & $\begin{array}{l}\text { Bulgaria, Czech Republic, } \\
\text { Croatia, Hungary, Poland, } \\
\text { Romania, Slovak Republic, } \\
\text { Slovenia }\end{array}$ & $\begin{array}{l}\text { Prime Ministers of CEFTA countries at a summit in } \\
\text { Bratislava expressed the wish that Croatia be } \\
\text { admitted to this organization by the end of the year. }\end{array}$ & 5 Dec. 2002 \\
\hline EC (25) Enlargement & 10 Oct. 2002 & Deal & $\begin{array}{l}\text { Austria, Belgium, Czech } \\
\text { Republic, Cyprus, Denmark, } \\
\text { Estonia, Finland, France, } \\
\text { Germany, Greece, Hungary, } \\
\text { Ireland, Italy, Latvia, } \\
\text { Lithuania, Luxembourg, Malta, } \\
\text { Netherlands, Poland, } \\
\text { Portugal, Slovak Republic, } \\
\text { Slovenia, Spain, Sweden, } \\
\text { United Kingdom }\end{array}$ & $\begin{array}{l}\text { The European Commission gave its green light } \\
\text { Wednesday for } 10 \text { countries to join the EU in 2004, in } \\
\text { a historic enlargement [...] recommended that Malta, } \\
\text { Cyprus, Estonia, Hungary, Poland, the Czech } \\
\text { Republic, Slovenia, Latvia, Lithuania and Slovakia be } \\
\text { invited to join in } 2004 \text {. }\end{array}$ & 16 April 2003 \\
\hline South Korea - Chile & 24 Oct. 2002 & Deal & Chile, South Korea & $\begin{array}{l}\text { South Korea and Chile concluded a FTA Thursday to } \\
\text { boost trade in South Korean industrial goods and } \\
\text { Chilean farm products, officials said. }\end{array}$ & 1 Feb. 2003 \\
\hline $\begin{array}{l}\text { Trans-Pacific Strategic } \\
\text { Economic Partnership }\end{array}$ & 28 Oct. 2002 & Start & $\begin{array}{l}\text { Chile, New Zealand, } \\
\text { Singapore }\end{array}$ & $\begin{array}{l}\text { Singapore, Chile and New Zealand have agreed to } \\
\text { begin negotiations on a trilateral trade agreement on } \\
\text { Saturday. }\end{array}$ & --- \\
\hline Singapore - Australia & 4 Nov. 2002 & Deal & Australia, Singapore & $\begin{array}{l}\text { Australia and Singapore have sealed a free trade } \\
\text { pact that will remove all tariffs on goods and services } \\
\text { by early } 2003 \text { [..] Australian Trade Minister Vaile } \\
\text { announced Sunday. }\end{array}$ & 17 Feb. 2003 \\
\hline US - Australia & 14 Nov. 2002 & Start & Australia, United States & $\begin{array}{l}\text { U.S. and Australia will begin negotiations toward a } \\
\text { free-trade agreement [...] U.S. Trade Representative } \\
\text { Zoellick said Thursday. }\end{array}$ & $\begin{array}{ll}-- \\
\end{array}$ \\
\hline US - Singapore & 20 Nov. 2002 & Deal & Singapore, United States & $\begin{array}{l}\text { Historic free-trade pact [..] - in the wee hours of } \\
\text { yesterday - will lead to the signing of a free-trade } \\
\text { agreement (FTA) between the United States and } \\
\text { Singapore next year. }\end{array}$ & 6 May 2003 \\
\hline US - Chile & 11 Dec. 2002 & Deal & Chile, United States & $\begin{array}{l}\text { U.S. Trade Representative announced today the } \\
\text { completion of a trade agreement between the United } \\
\text { States and Chile. }\end{array}$ & 6 June 2003 \\
\hline EFTA - Lebanon & 12 Dec. 2002 & Start & $\begin{array}{l}\text { Iceland, Lebanon, Norway, } \\
\text { Switzerland }\end{array}$ & $\begin{array}{l}\text { EFTA signed a Joint Declaration of Co-operation with } \\
\text { Lebanon, which could lead to negotiations on a FTA. }\end{array}$ & $\begin{array}{ll}-- \\
\end{array}$ \\
\hline $\begin{array}{l}\text { Dominican Republic - Central } \\
\text { America - United States Free } \\
\text { Trade Agreement (CAFTA- } \\
\text { DR) }\end{array}$ & 8 Jan. 2003 & Start & Costa Rica, United States & $\begin{array}{l}\text { U.S. Trade Representative Zoellick and ministers } \\
\text { from Costa Rica, El Salvador, Guatemala, Honduras } \\
\text { and Nicaragua announced the launch of negotiations } \\
\text { to conclude a U.S.-Central American Free Trade }\end{array}$ & $\begin{array}{ll}-- \\
\end{array}$ \\
\hline
\end{tabular}




\begin{tabular}{|c|c|c|c|c|c|}
\hline & & & & Agreement (CAFTA). & \\
\hline EFTA - GCC & 12 Jan. 2003 & Start & $\begin{array}{l}\text { Bahrain, Iceland, Kuwait, } \\
\text { Norway, Oman, Saudi Arabia, } \\
\text { Switzerland }\end{array}$ & $\begin{array}{l}\text { Gulf Cooperation Council (GCC) hosts a joint } \\
\text { committee meeting here on Tuesday with EFTA [..] } \\
\text { with the aim of striking a free trade agreement, the } \\
\text { statement said. }\end{array}$ & --- \\
\hline India - Singapore & 4 Feb. 2003 & Start & India, Singapore & $\begin{array}{l}\text { Singapore and India have agreed to launch } \\
\text { negotiations for a bilateral FTA by April 2003, the } \\
\text { press secretary for Singapore Prime Minister } \\
\text { announced Tuesday. }\end{array}$ & --- \\
\hline $\begin{array}{l}\text { Common Economic Zone } \\
\text { (CEZ) }\end{array}$ & 24 Feb. 2003 & Start & Ukraine, Russian Federation & $\begin{array}{l}\text { Presidents of Russia, Ukraine, Belarus and } \\
\text { Kazakhstan have agreed to form a free-trade zone } \\
\text { [..] in a statement signed Sunday. }\end{array}$ & --- \\
\hline EFTA - Chile & $\begin{array}{l}25 \text { March } \\
2003\end{array}$ & Deal & $\begin{array}{l}\text { Chile, Iceland, Norway, } \\
\text { Switzerland }\end{array}$ & $\begin{array}{l}\text { The government has reached an agreement with } \\
\text { EFTA states to establish a free-trade zone, Chilean } \\
\text { President Lagos said. }\end{array}$ & $\begin{array}{l}26 \text { June } \\
2003\end{array}$ \\
\hline Turkey - Tunisia & 19 May 2003 & Start & Tunisia, Turkey & $\begin{array}{l}\text { President Sezer said that this was his first official visit } \\
\text { to Tunisia and that he had proposed establishing a } \\
\text { FTA. }\end{array}$ & --- \\
\hline US - Bahrain & 21 May 2003 & Start & Bahrain, United States & $\begin{array}{l}\text { The White House said Wednesday it will begin } \\
\text { pursuing a FTA with Persian Gulf ally Bahrain, the } \\
\text { first such effort announced since President Bush this } \\
\text { month proposed a free trade zone in the Middle East. }\end{array}$ & --- \\
\hline EFTA - SACU & 22 May 2003 & Start & $\begin{array}{l}\text { Botswana, Iceland, Namibia, } \\
\text { Norway, South Africa, } \\
\text { Swaziland, Switzerland }\end{array}$ & $\begin{array}{l}\text { It was announced yesterday that SACU and EFTA } \\
\text { were planning to conclude an extensive FTA. }\end{array}$ & --- \\
\hline China - Hong Kong & 13 June 2003 & Deal & China, Hong Kong & $\begin{array}{l}\text { Hong Kong and China will complete bilateral FTA by } \\
\text { the end of this month, Secretary for Commerce, } \\
\text { Industry and Trade, Tangan official in the territory } \\
\text { confirmed Friday. }\end{array}$ & $\begin{array}{l}29 \text { June } \\
2003\end{array}$ \\
\hline Jordan - Singapore & 25 June 2003 & Start & Jordan, Singapore & $\begin{array}{l}\text { Jordan and Singapore agreed to begin negotiations } \\
\text { in the "near future" [..] A joint statement released this } \\
\text { week on the sidelines of the World Economic Forum } \\
(\text { WEF). }\end{array}$ & --- \\
\hline Panama - Taiwan & 8 Aug. 2003 & Deal & Panama, Taiwan & $\begin{array}{l}\text { Taiwan and Panama are due to sign a formal FTA } \\
\text { later this month after concluding the final round of } \\
\text { talks, Taiwan's economics minister Lin Yi-fu said } \\
\text { Friday }\end{array}$ & 21 Aug. 2003 \\
\hline $\begin{array}{l}\text { Common Economic Zone } \\
\text { (CEZ) }\end{array}$ & 19 Sept. 2003 & Deal & Ukraine, Russian Federation & $\begin{array}{l}\text { Ukraine, Russia, Belarus, and Kazakhstan reached a } \\
\text { consensus on practically all problems, Ukrainian } \\
\text { President Kuchma noted. }\end{array}$ & $\begin{array}{l}19 \text { Sept. } \\
2003\end{array}$ \\
\hline
\end{tabular}




\begin{tabular}{|c|c|c|c|c|c|}
\hline Turkey - Morocco & 8 Oct. 2003 & Deal & Morocco, Turkey & $\begin{array}{l}\text { Morocco and Turkey have initialed a FTA [..] } \\
\text { According to a Foreign Trade Ministry press release. }\end{array}$ & 7 April 2004 \\
\hline ASEAN - Japan & 8 Oct. 2003 & Start & $\begin{array}{l}\text { Indonesia, Japan, Malaysia, } \\
\text { Philippines, Singapore, } \\
\text { Thailand, Vietnam }\end{array}$ & $\begin{array}{l}\text { Leaders of Japan and the ASEAN decided } \\
\text { Wednesday to kick off formal negotiations in early } \\
2004 \text { to establish a regional free trade area. }\end{array}$ & --- \\
\hline Thailand - Australia & 20 Oct. 2003 & Deal & Australia, Thailand & $\begin{array}{l}\text { Australia reached a free trade and investment deal } \\
\text { with Thailand on Sunday [..] said Prime Minister } \\
\text { Howard. }\end{array}$ & 5 July 2004 \\
\hline Thailand - New Zealand & 20 Oct. 2003 & Start & New Zealand, Thailand & $\begin{array}{l}\text { Thai Prime Minister Shinawatra and his New Zealand } \\
\text { counterpart Ms. Clark agreed to initiate a FTA on } \\
\text { Monday. }\end{array}$ & --- \\
\hline South Korea - Singapore & 23 Oct. 2003 & Start & South Korea, Singapore & $\begin{array}{l}\text { Singapore and South Korea agreed to launch formal } \\
\text { negotiations for a bilateral FTA early next year, the } \\
\text { leaders of the two countries announced on Thursday. }\end{array}$ & --- \\
\hline $\begin{array}{l}\text { US - Colombia / US - } \\
\text { Panama / US - Peru }\end{array}$ & 18 Nov. 2003 & Start & $\begin{array}{l}\text { Colombia, United States; } \\
\text { Panama; Peru }\end{array}$ & $\begin{array}{l}\text { U.S. Trade Representative Zoellick said Tuesday it } \\
\text { was opening free-trade negotiations Colombia, Peru, } \\
\text { Ecuador, Bolivia and Panama. }\end{array}$ & --- \\
\hline $\begin{array}{l}\text { Japan - Malaysia / Japan - } \\
\text { Philippines / Japan - Thailand }\end{array}$ & 11 Dec. 2003 & Start & $\begin{array}{l}\text { Japan, Malaysia; Philippines; } \\
\text { Thailand }\end{array}$ & $\begin{array}{l}\text { Japan stepped up its efforts for regional trade } \\
\text { liberalization, saying it would start bilateral trade talks } \\
\text { with Malaysia, Thailand and the Philippines. }\end{array}$ & --- \\
\hline $\begin{array}{l}\text { South Asian Free Trade } \\
\text { Agreement (SAFTA) }\end{array}$ & 5 Jan. 2004 & Deal & $\begin{array}{l}\text { Bangladesh, India, Nepal, } \\
\text { Pakistan, Sri Lanka }\end{array}$ & $\begin{array}{l}\text { A South Asian free trade agreement reached ahead } \\
\text { of a major regional summit will let countries protect } \\
\text { highly sensitive industries, Pakistan's foreign minister } \\
\text { said. }\end{array}$ & 6 Jan. 2004 \\
\hline $\begin{array}{l}\text { Dominican Republic - Central } \\
\text { America - United States Free } \\
\text { Trade Agreement (CAFTA- } \\
\text { DR) }\end{array}$ & 26 Jan. 2004 & Deal & Costa Rica, United States & $\begin{array}{l}\text { Costa Rica reached a FTA Sunday in Washington } \\
\text { with the United States [..] Foreign Trade Minister } \\
\text { Trejos told reporters. }\end{array}$ & 5 Aug. 2004 \\
\hline US - Australia & 9 Feb. 2004 & Deal & Australia, United States & $\begin{array}{l}\text { United States and Australia reached a free-trade } \\
\text { agreement [..] was struck after a telephone call } \\
\text { between President Bush and Australia's Prime } \\
\text { Minister Howard. }\end{array}$ & 18 May 2004 \\
\hline Panama - Singapore & 17 Feb. 2004 & Start & Panama, Singapore & $\begin{array}{l}\text { Singapore and Panama announced they had decided } \\
\text { to start negotiations on a bilateral FTA with the aim of } \\
\text { completing talks within a year [..] joint statement } \\
\text { released Tuesday. }\end{array}$ & --- \\
\hline US - Morocco & 2 March 2004 & Deal & Morocco, United States & $\begin{array}{l}\text { United States concluded a FTA with Morocco, } \\
\text { officials said Tuesday, following delays to settle } \\
\text { issues over key sectors including agriculture and } \\
\text { textiles. }\end{array}$ & $\begin{array}{l}15 \text { June } \\
2004\end{array}$ \\
\hline
\end{tabular}




\begin{tabular}{|c|c|c|c|c|c|}
\hline Japan - Mexico & $\begin{array}{l}15 \text { March } \\
2004\end{array}$ & Deal & Japan, Mexico & $\begin{array}{l}\text { Japan and Mexico reached a final agreement [..] said } \\
\text { Japanese Trade Minister late Friday [..] after } \\
\text { concessions over sensitive agricultural items. }\end{array}$ & $\begin{array}{l}17 \text { Sept. } \\
2004\end{array}$ \\
\hline Jordan - Singapore & 10 May 2004 & Deal & Jordan, Singapore & $\begin{array}{l}\text { Singapore and Jordan have successfully concluded } \\
\text { negotiations on a FTA and a separate bilateral } \\
\text { investment treaty [... Singapore's Ministry of Trade } \\
\text { and Industry (MTI) said in a statement late Friday. }\end{array}$ & 16 May 2004 \\
\hline US - Bahrain & 27 May 2004 & Deal & Bahrain, United States & $\begin{array}{l}\text { United States has successfully concluded } \\
\text { negotiations for a FTA with Bahrain, wrapping up the } \\
\text { negotiations in just four months, both countries } \\
\text { announced Thursday. }\end{array}$ & $\begin{array}{l}14 \text { Sept. } \\
2005\end{array}$ \\
\hline EFTA - Lebanon & 24 June 2004 & Deal & $\begin{array}{l}\text { Iceland, Lebanon, Norway, } \\
\text { Switzerland }\end{array}$ & $\begin{array}{l}\text { The four-nation European Free Trade Association } \\
\text { and Lebanon signed a FTA on Thursday, EFTA said. }\end{array}$ & $\begin{array}{l}17 \text { June } \\
2002\end{array}$ \\
\hline $\begin{array}{l}\text { Dominican Republic - Central } \\
\text { America - United States Free } \\
\text { Trade Agreement (CAFTA- } \\
\text { DR) }\end{array}$ & 23 July 2004 & Deal & Costa Rica, United States & $\begin{array}{l}\text { The Dominican Republic will join a proposed free- } \\
\text { trade pact with the United States and five countries } \\
\text { of Central America known as CAFTA, US officials } \\
\text { said Friday. }\end{array}$ & 5 Aug. 2004 \\
\hline Turkey - Tunisia & 28 Sept. 2004 & Deal & Tunisia, Turkey & $\begin{array}{l}\text { Tunisia and Turkey have concluded a free-trade } \\
\text { agreement [..] under which Tunisia will be able to } \\
\text { export to Europe products made with Turkish textiles. }\end{array}$ & 25 Nov. 2004 \\
\hline EC (27) Enlargement & 6 Oct. 2004 & Deal & $\begin{array}{l}\text { Austria, Belgium, Bulgaria, } \\
\text { Czech Republic, Cyprus, } \\
\text { Denmark, Estonia, Finland, } \\
\text { France, Germany, Greece, } \\
\text { Hungary, Ireland, Italy, Latvia, } \\
\text { Lithuania, Luxembourg, Malta, } \\
\text { Netherlands, Poland, } \\
\text { Portugal, Romania, Slovak } \\
\text { Republic, Slovenia, Spain, } \\
\text { Sweden, United Kingdom }\end{array}$ & $\begin{array}{l}\text { The European Union's (EU) executive recommended } \\
\text { Wednesday that the bloc sign accession treaties with } \\
\text { Romania and Bulgaria as early as } 2005 \text {. }\end{array}$ & 25 April 2005 \\
\hline ASEAN - China & 26 Oct. 2004 & Deal & $\begin{array}{l}\text { China, Indonesia, Malaysia, } \\
\text { Philippines, Singapore, } \\
\text { Thailand, Vietnam }\end{array}$ & $\begin{array}{l}\text { China and ASEAN will sign a FTA in November to } \\
\text { cut tariffs on commodities from } 2005 \text { and eliminate } \\
\text { them by 2010, the Ministry of Commerce said } \\
\text { Tuesday. }\end{array}$ & 29 Nov. 2004 \\
\hline ASEAN - China (Services) & 4 Nov. 2004 & Start & $\begin{array}{l}\text { China, Indonesia, Malaysia, } \\
\text { Philippines, Singapore, } \\
\text { Thailand, Vietnam }\end{array}$ & $\begin{array}{l}\text { China and ASEAN will start free trade talks on } \\
\text { services and investment after signing a trade } \\
\text { agreement later this month, ASEAN official said. }\end{array}$ & --- \\
\hline US - Oman & 15 Nov. 2004 & Start & Oman, United States & $\begin{array}{l}\text { U.S. Trade Representative Zoellick announced plans } \\
\text { Monday to negotiate free trade agreements with } \\
\text { Oman. }\end{array}$ & 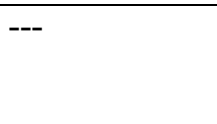 \\
\hline
\end{tabular}




\begin{tabular}{|c|c|c|c|c|c|}
\hline Chile - China & 18 Nov. 2004 & Start & Chile, China & $\begin{array}{l}\text { Chinese President Jintao and Chilean President } \\
\text { Lagos said Thursday they have agreed to commence } \\
\text { negotiations for a bilateral FTA. }\end{array}$ & --- \\
\hline Japan - Philippines & 19 Nov. 2004 & Deal & Japan, Philippines & $\begin{array}{l}\text { Japan and the Philippines on Thursday reached a } \\
\text { basic agreement to conclude a bilateral free trade } \\
\text { pact, Japan's Economy, Trade and Industry Minister } \\
\text { Nakagawa said. }\end{array}$ & 9 Sept. 2006 \\
\hline China - New Zealand & 19 Nov. 2004 & Start & China, New Zealand & $\begin{array}{l}\text { China and New Zealand will move toward signing a } \\
\text { FTA [..] a senior Chinese official said. }\end{array}$ & --- \\
\hline Singapore - Peru & 19 Nov. 2004 & Start & Peru, Singapore & $\begin{array}{l}\text { Peruvian President Toledo and Singaporean Prime } \\
\text { Minister Loong agreed Friday to start negotiations for } \\
\text { a bilateral FTA [..] announced on the sidelines of the } \\
\text { Apec summit. }\end{array}$ & --- \\
\hline Pakistan - Sri Lanka & 22 Nov. 2004 & Deal & Pakistan, Sri Lanka & $\begin{array}{l}\text { Sri Lanka and Pakistan will launch a FTA by January } \\
\text { when President Kumaratunga visits Islamabad, } \\
\text { Pakistan Prime Minister Aziz said Monday. }\end{array}$ & 1 Aug. 2002 \\
\hline South Korea - Singapore & 29 Nov. 2004 & Deal & Singapore, South Korea & $\begin{array}{l}\text { Asian economies South Korea and Singapore } \\
\text { concluded a FTA during a regional summit in Laos, } \\
\text { the South Korean government announced Monday. }\end{array}$ & 4 Aug. 2005 \\
\hline Thailand - New Zealand & 1 Dec. 2004 & Deal & New Zealand, Thailand & $\begin{array}{l}\text { Prime Ministers of New Zealand and Thailand } \\
\text { announced in Vientiane, Laos, Wednesday that } \\
\text { negotiations on FTA had been substantively } \\
\text { concluded. }\end{array}$ & 19 April 2005 \\
\hline EFTA - South Korea & 10 Dec. 2004 & Start & $\begin{array}{l}\text { Iceland, Norway, South } \\
\text { Korea, Switzerland }\end{array}$ & $\begin{array}{l}\text { South Korea will start talks on a free trade agreement } \\
\text { with the EFTA in late January, the Ministry of Foreign } \\
\text { Affairs and Trade said Friday. }\end{array}$ & --- \\
\hline EFTA - Tunisia & 16 Dec. 2004 & Deal & $\begin{array}{l}\text { Iceland, Norway, Switzerland, } \\
\text { Tunisia }\end{array}$ & $\begin{array}{l}\text { Tunisia and the European Free Trade Association } \\
\text { (EFTA), sign a FTA [... it was announced Thursday. }\end{array}$ & 17 Dec. 2004 \\
\hline Chile - India & 20 Jan. 2005 & Start & Chile, India & $\begin{array}{l}\text { The Indian government has approved bilateral } \\
\text { economic framework agreement with Chile [..] paving } \\
\text { the way for full free-trade talks. }\end{array}$ & --- \\
\hline Pakistan - Malaysia & 16 Feb. 2005 & Start & Malaysia, Pakistan & $\begin{array}{l}\text { Pakistan and Malaysia have agreed to start } \\
\text { discussions on a PTA leading to a FTA, Pakistani } \\
\text { Prime Minister Aziz said. }\end{array}$ & --- \\
\hline Egypt - Turkey & $\begin{array}{l}31 \text { March } \\
2005\end{array}$ & Deal & Egypt, Turkey & $\begin{array}{l}\text { Turkish State Minister Tuzmen said on Thursday said } \\
\text { that he and Egyptian Foreign Trade and Industry } \\
\text { Minister Rashid would sign a free trade agreement in } \\
\text { June. }\end{array}$ & 27 Dec. 2005 \\
\hline Pakistan - China & 6 April 2005 & Start & China, Pakistan & $\begin{array}{l}\text { Minister for Commerce Khan Wednesday said that } \\
\text { Pakistan and China have started negotiations for a }\end{array}$ & --- \\
\hline
\end{tabular}




\begin{tabular}{|c|c|c|c|c|c|}
\hline & & & & FTA. & \\
\hline Panama - Singapore & 8 April 2005 & Deal & Panama, Singapore & $\begin{array}{l}\text { Singapore and Panama have concluded a free trade } \\
\text { agreement, the two sides announced Friday. }\end{array}$ & $\begin{array}{l}1 \text { March } \\
2006\end{array}$ \\
\hline Japan - Malaysia & 23 May 2005 & Deal & Japan, Malaysia & $\begin{array}{l}\text { "We have now finalized everything," International } \\
\text { Trade and Industry Minister Aziz told reporters after } \\
\text { talks with visiting Japanese Trade Minister } \\
\text { Nakagawa. }\end{array}$ & 13 Dec. 2005 \\
\hline Japan - Indonesia & 1 June 2005 & Start & Indonesia, Japan & $\begin{array}{l}\text { Japan and Indonesia agreed on Wednesday to begin } \\
\text { negotiations over a FTA as early as next month [..] } \\
\text { said the official at the Ministry of Economy, Trade } \\
\text { and Industry. }\end{array}$ & --- \\
\hline $\begin{array}{l}\text { Trans-Pacific Strategic } \\
\text { Economic Partnership }\end{array}$ & 3 June 2005 & Deal & $\begin{array}{l}\text { Chile, New Zealand, } \\
\text { Singapore }\end{array}$ & $\begin{array}{l}\text { Brunei, Chile, New Zealand and Singapore have } \\
\text { agreed to create the first trans-Pacific free-trade } \\
\text { agreement, officials said Friday. }\end{array}$ & 18 July 2005 \\
\hline India - Singapore & 20 June 2005 & Deal & India, Singapore & $\begin{array}{l}\text { The cabinet today gave its approval to a } \\
\text { comprehensive trade agreement between India and } \\
\text { Singapore, told Information and Broadcasting } \\
\text { Minister Reddy reporters. }\end{array}$ & $\begin{array}{l}29 \text { June } \\
2005\end{array}$ \\
\hline EFTA - South Korea & 12 July 2005 & Deal & $\begin{array}{l}\text { Iceland, Norway, South } \\
\text { Korea, Switzerland }\end{array}$ & $\begin{array}{l}\text { Korea and EFTA agreed to a FTA [..] the Ministry of } \\
\text { Foreign Affairs and Trade said [..] reached during a } \\
\text { small WTO ministerial meeting. }\end{array}$ & 15 Dec. 2005 \\
\hline Japan - Thailand & 1 Aug. 2005 & Deal & Japan, Thailand & $\begin{array}{l}\text { Japanese Minister of Economy, Trade and Industry } \\
\text { Nakagawa reached the basic accord with Thai } \\
\text { Deputy Prime Minister Chatusiphithak. }\end{array}$ & 3 April 2007 \\
\hline US - Oman & 3 Oct. 2005 & Deal & Oman, United States & $\begin{array}{l}\text { United States and Oman announced on Monday they } \\
\text { have successfully completed negotiations on a FTA. }\end{array}$ & 19 Jan. 2006 \\
\hline Chile - China & 28 Oct. 2005 & Deal & Chile, China & $\begin{array}{l}\text { Chilean President Lagos confirmed his Foreign } \\
\text { Minister's announcement that negotiations on the } \\
\text { Chile-China FTA had come to a successful end } \\
\text { today. }\end{array}$ & 18 Nov. 2005 \\
\hline Chile - Japan & 18 Nov. 2005 & Start & Chile, Japan & $\begin{array}{l}\text { Japan and Chile agreed Friday to officially launch } \\
\text { negotiations aimed at producing a bilateral free trade } \\
\text { agreement, a Japanese official said. }\end{array}$ & --- \\
\hline Chile - India & 24 Nov. 2005 & Deal & India, Chile & $\begin{array}{l}\text { The agreement will benefit } 91 \text { percent of Indian } \\
\text { exports and } 98 \text { percent of imports from Chile, the } \\
\text { Embassy of Chile said in a statement here on } \\
\text { Thursday. }\end{array}$ & $\begin{array}{l}8 \text { March } \\
2006\end{array}$ \\
\hline US - Peru & 7 Dec. 2005 & Deal & Peru, United States & $\begin{array}{l}\text { United States and Peru have wrapped up } \\
\text { negotiations on a FTA, officials from both countries } \\
\text { said Wednesday. }\end{array}$ & 12 April 2006 \\
\hline
\end{tabular}




\begin{tabular}{|c|c|c|c|c|c|}
\hline Japan - Viet Nam & 12 Dec. 2005 & Start & Japan, Viet Nam & $\begin{array}{l}\text { Japanese Prime Minister Koizumi and his } \\
\text { Vietnamese counterpart agreed Monday to launch } \\
\text { formal negotiations. }\end{array}$ & --- \\
\hline South Korea - US & 2 Feb. 2006 & Start & South Korea, United States & $\begin{array}{l}\text { South Korea and the United States are to start formal } \\
\text { talks on establishing a FTA and hope to complete } \\
\text { negotiations within a year, officials said Thursday. }\end{array}$ & --- \\
\hline Panama - Chile & 6 Feb. 2006 & Deal & Chile, Panama & $\begin{array}{l}\text { Panama and Chile signed a free trade deal here on } \\
\text { Saturday, ending their 15th round of FTA talks [..] the } \\
\text { two sides excluded some sensitive issues [..] said } \\
\text { Panama's Minister of Commerce and Industry Ferrer. }\end{array}$ & $\begin{array}{l}27 \text { June } \\
2006\end{array}$ \\
\hline US - Colombia & 27 Feb. 2006 & Deal & Colombia, United States & $\begin{array}{l}\text { United States and Colombia have concluded a trade } \\
\text { agreement [... announced Monday by USTR Portman } \\
\text { and Colombia's minister for trade, industry and } \\
\text { tourism. }\end{array}$ & 22 Nov. 2006 \\
\hline EFTA - SACU & 26 June 2006 & Deal & $\begin{array}{l}\text { Botswana, Iceland, Namibia, } \\
\text { Norway, South Africa, } \\
\text { Switzerland }\end{array}$ & $\begin{array}{l}\text { Conclusion of FTA with SACU (South Africa, } \\
\text { Botswana, Lesotho, Namibia and Swaziland ) will } \\
\text { open new doors, said Swiss Economics Minister } \\
\text { Deiss. }\end{array}$ & $\begin{array}{l}26 \text { June } \\
2006\end{array}$ \\
\hline Chile - Colombia & 27 July 2006 & Start & Chile, Colombia & $\begin{array}{l}\text { Chile and Colombia announced they have agreed to } \\
\text { start negotiations toward a FTA on Thursday [..] after } \\
\text { a meeting between Foreign Minister Foxley and } \\
\text { visiting Colombian Trade Minister Botero. }\end{array}$ & --- \\
\hline China - Singapore & 25 Aug. 2006 & Start & China, Singapore & $\begin{array}{l}\text { China and Singapore have agreed to launch } \\
\text { negotiations for a bilateral free trade agreement, } \\
\text { Singapore's Trade and Industry Ministry said Friday. }\end{array}$ & --- \\
\hline Chile - Japan & 22 Sept. 2006 & Deal & Chile, Japan & $\begin{array}{l}\text { Japan announced Friday a framework free trade deal } \\
\text { with Chile [...] sealed after just seven months of } \\
\text { negotiations [..] said Prime Minister Koizumi. }\end{array}$ & $\begin{array}{l}27 \text { March } \\
2007\end{array}$ \\
\hline EFTA - Colombia & 5 Oct. 2006 & Start & $\begin{array}{l}\text { Colombia, Iceland, Norway, } \\
\text { Switzerland }\end{array}$ & $\begin{array}{l}\text { Colombia and EFTA began talks Thursday aimed at } \\
\text { drafting a trade agreement [..] said Colombian Trade } \\
\text { Minister Botero following the meeting in Bogota. }\end{array}$ & --- \\
\hline EFTA - Egypt & 1 Nov. 2006 & Deal & $\begin{array}{l}\text { Egypt, Iceland, Norway, } \\
\text { Switzerland }\end{array}$ & $\begin{array}{l}\text { Egypt and EFTA have agreed to establish a free } \\
\text { trade zone between the two sides, Egypt's news } \\
\text { agency MENA reported on Wednesday. }\end{array}$ & 27 Jan. 2007 \\
\hline Australia - Chile & 10 Nov. 2006 & Start & Australia, Chile & $\begin{array}{l}\text { Chile and Australia agreed on Friday to start bilateral } \\
\text { free trade talks, according to a statement issued by } \\
\text { Chile's Foreign Ministry. }\end{array}$ & --- \\
\hline Pakistan - China & 13 Nov. 2006 & Deal & China, Pakistan & $\begin{array}{l}\text { China and Pakistan have wrapped up negotiations } \\
\text { [... announcement ahead of a state visit by Chinese } \\
\text { President Jintao to Pakistan. }\end{array}$ & 24 Nov. 2006 \\
\hline
\end{tabular}




\begin{tabular}{|c|c|c|c|c|c|}
\hline Chile - Colombia & 27 Nov. 2006 & Deal & Chile, Colombia & $\begin{array}{l}\text { Presidents of Chile and Colombia signed a FTA } \\
\text { during a visit to Bogota. }\end{array}$ & 27 Nov. 2006 \\
\hline Japan - Indonesia & 28 Nov. 2006 & Deal & Indonesia, Japan & $\begin{array}{l}\text { Japan and Indonesia said Tuesday they have in } \\
\text { principle reached a bilateral FTA [..] said in a joint } \\
\text { statement. }\end{array}$ & 20 Aug. 2007 \\
\hline US - Panama & 19 Dec. 2006 & Deal & Panama, United States & $\begin{array}{l}\text { The office of U.S. Trade Representative Schwab said } \\
\text { Tuesday it had virtually wrapped up a FTA with } \\
\text { Panama [..] the pact complete save for further talks } \\
\text { on labor issues. }\end{array}$ & $\begin{array}{l}28 \text { June } \\
2007\end{array}$ \\
\hline ASEAN - China (Services) & 15 Jan. 2007 & Deal & $\begin{array}{l}\text { China, Indonesia, Malaysia, } \\
\text { Philippines, Singapore, } \\
\text { Thailand, Vietnam }\end{array}$ & $\begin{array}{l}\text { China and the ASEAN signed on Sunday an } \\
\text { agreement on Trade in Services of the China-ASEAN } \\
\text { Free Trade Area. }\end{array}$ & 14 Jan. 2007 \\
\hline Japan - Switzerland & 19 Jan. 2007 & Start & Japan, Switzerland & $\begin{array}{l}\text { Japan and Switzerland agreed Friday to begin } \\
\text { negotiations for a bilateral FTA [..] after a telephone } \\
\text { conversation between Japanese Prime Minister and } \\
\text { Swiss President. }\end{array}$ & --- \\
\hline Canada - Peru & 23 Jan. 2007 & Start & Canada, Peru & $\begin{array}{l}\text { Peru and Canada will start talks over a FTA in the } \\
\text { next two or three weeks, said Peru's Foreign Trade } \\
\text { Deputy Minister Garcia. }\end{array}$ & --- \\
\hline South Korea - US & 2 April 2007 & Deal & South Korea, United States & $\begin{array}{l}\text { United States and South Korea concluded a } \\
\text { landmark FTA Monday, officials said, culminating } 10 \\
\text { months of negotiations in a final week of intense } \\
\text { haggling that just beat a key U.S. legislative } \\
\text { deadline. }\end{array}$ & 30 July 2007 \\
\hline EFTA - Canada & 7 June 2007 & Deal & $\begin{array}{l}\text { Canada, Iceland, Norway, } \\
\text { Switzerland }\end{array}$ & $\begin{array}{l}\text { Canada and EFTA have concluded talks on a FTA } \\
\text { Canadian Trade Minister Emerson announced } \\
\text { Thursday. }\end{array}$ & 26 Jan. 2008 \\
\hline Canada - Colombia & 7 June 2007 & Start & Canada, Colombia & $\begin{array}{l}\text { Canadian Trade Minister Emerson announced } \\
\text { Thursday that Canada is launching free trade talks } \\
\text { with Colombia. }\end{array}$ & --- \\
\hline Pakistan - Malaysia & 11 June 2007 & Deal & Malaysia, Pakistan & $\begin{array}{l}\text { Pakistan, Malaysia to sign FTA [..] mutual consent } \\
\text { was expressed during a telephonic conversation } \\
\text { between the two prime ministers this afternoon. }\end{array}$ & 8 Nov. 2007 \\
\hline Canada - Jordan & 13 July 2007 & Start & Canada, Jordan & $\begin{array}{l}\text { Prime Minister Harper and visiting King Abdullah II } \\
\text { bin Al-Hussein of Jordan [..] announced plans to } \\
\text { begin talks next year on a possible Canada-Jordan } \\
\text { FTA. }\end{array}$ & --- \\
\hline Peru - Singapore & 4 Sept. 2007 & Deal & Peru, Singapore & $\begin{array}{l}\text { Singapore and Peru have concluded negotiations for } \\
\text { a FTA and the bilateral accord will be signed in the } \\
\text { next few months, the two nations said Tuesday. }\end{array}$ & 29 May 2008 \\
\hline
\end{tabular}




\begin{tabular}{|c|c|c|c|c|c|}
\hline ASEAN - Japan & 12 Nov. 2007 & Deal & $\begin{array}{l}\text { Indonesia, Japan, Malaysia, } \\
\text { Philippines, Singapore, } \\
\text { Thailand, Vietnam }\end{array}$ & $\begin{array}{l}\text { Japan and ASEAN on Wednesday welcomed and } \\
\text { effectively endorsed the conclusion of a } \\
\text { comprehensive FTA aimed at stimulating further } \\
\text { trade and investment between the two sides. }\end{array}$ & $\begin{array}{l}26 \text { March } \\
2008\end{array}$ \\
\hline EC - Cote d'Ivoire & 7 Dec. 2007 & Start & $\begin{array}{l}\text { Austria, Belgium, Bulgaria, } \\
\text { Czech Republic, Cote d'lvoire, } \\
\text { Cyprus, Denmark, Estonia, } \\
\text { Finland, France, Germany, } \\
\text { Greece, Hungary, Ireland, } \\
\text { Italy, Latvia, Lithuania, } \\
\text { Luxembourg, Malta, } \\
\text { Netherlands, Poland, } \\
\text { Portugal, Romania, Slovak } \\
\text { Republic, Slovenia, Spain, } \\
\text { Sweden, United Kingdom }\end{array}$ & $\begin{array}{l}\text { Cote d'Ivoire Friday initialed an interim trade deal } \\
\text { with the European Commission ahead new } \\
\text { agreements to replace preferential accords between } \\
\text { the EU and African, Caribbean and Pacific (ACP) } \\
\text { nations. }\end{array}$ & --- \\
\hline $\begin{array}{l}\text { EC - CARIFORUM States } \\
\text { EPA }\end{array}$ & 17 Dec. 2007 & Deal & $\begin{array}{l}\text { Austria, Barbados, Belgium, } \\
\text { Bulgaria, Czech Republic, } \\
\text { Cyprus, Denmark, Estonia, } \\
\text { Finland, France, Germany, } \\
\text { Greece, Hungary, Ireland, } \\
\text { Italy, Jamaica, Latvia, } \\
\text { Lithuania, Luxembourg, Malta, } \\
\text { Netherlands, Poland, } \\
\text { Portugal, Romania, Slovak } \\
\text { Republic, Slovenia, Spain, } \\
\text { Sweden, Trinidad and } \\
\text { Tobago, United Kingdom }\end{array}$ & $\begin{array}{l}\text { Caricom and Dominican Republic - countries have } \\
\text { reached agreement with the EU on a new Economic } \\
\text { Partnership Agreement (EPA), just days before the } \\
\text { current Cotonou Agreement expires at yearend [..] } \\
\text { inked the deal in Bridgetown on Sunday. }\end{array}$ & 15 Oct. 2008 \\
\hline China - New Zealand & 24 Jan. 2008 & Deal & China, New Zealand & $\begin{array}{l}\text { China and New Zealand will sign the FTA in April, the } \\
\text { Chinese Ministry of Commerce announced here } \\
\text { Thursday. }\end{array}$ & 7 April 2008 \\
\hline Canada - Peru & 28 Jan. 2008 & Deal & Canada, Peru & $\begin{array}{l}\text { Peru has signed a FTA with Canada, Peruvian } \\
\text { President Garcia announced at the World Economic } \\
\text { Forum on Saturday. }\end{array}$ & 29 May 2008 \\
\hline EFTA - GCC & 29 April 2008 & Deal & $\begin{array}{l}\text { Bahrain, Iceland, Norway, } \\
\text { Oman, Saudi Arabia, } \\
\text { Switzerland, United Arab } \\
\text { Emirates. }\end{array}$ & $\begin{array}{l}\text { Negotiations for a FTA between the states of the Gulf } \\
\text { Cooperation Council (GCC) and the European Free } \\
\text { Trade Association (EFTA) have been finalized, said } \\
\text { Secretary General of the GCC Mr. Al-Atiyya. }\end{array}$ & $\begin{array}{l}22 \text { June } \\
2009\end{array}$ \\
\hline Australia - Chile & 27 May 2008 & Deal & Australia, Chile & $\begin{array}{l}\text { Australia and Chile have sealed negotiations for a } \\
\text { FTA and the deal should be in place by } 2009 \text {, }\end{array}$ & 30 July 2008 \\
\hline
\end{tabular}




\begin{tabular}{|c|c|c|c|c|c|}
\hline & & & & Australian Trade Minister Crean said Tuesday. & \\
\hline Canada - Colombia & 9 June 2008 & Deal & Canada, Colombia & $\begin{array}{l}\text { Colombia has concluded negotiations for a free trade } \\
\text { deal with Canada [...] Canada's Foreign Affairs and } \\
\text { International Trade Ministry said Saturday. }\end{array}$ & N/A \\
\hline EFTA - Colombia & 1 July 2008 & Deal & $\begin{array}{l}\text { Colombia, Iceland, Norway, } \\
\text { Switzerland }\end{array}$ & $\begin{array}{l}\text { Colombia and EFTA have agreed on a FTA, } \\
\text { according to a press release by the Colombian } \\
\text { government on Tuesday. }\end{array}$ & 25 Nov. 2008 \\
\hline Canada - Jordan & 26 Aug. 2008 & Deal & Canada, Jordan & $\begin{array}{l}\text { Department of Foreign Affairs and International } \\
\text { Trade said Tuesday that it has reached a free trade } \\
\text { agreement with Jordan. }\end{array}$ & $\begin{array}{l}28 \text { June } \\
2009\end{array}$ \\
\hline China - Singapore & 4 Sept. 2008 & Deal & China, Singapore & $\begin{array}{l}\text { Singapore's Deputy Prime Minister Seng and } \\
\text { Chinese Vice-Premier Qishan yesterday announced } \\
\text { the successful end to two years of FTA negotiations. }\end{array}$ & 23 Oct. 2008 \\
\hline $\begin{array}{l}\text { Japan - Switzerland / Japan - } \\
\text { Viet Nam }\end{array}$ & 29 Sept. 2008 & Deal & Japan, Switzerland; Vietnam & $\begin{array}{l}\text { Japan has struck separate basic deals with Vietnam } \\
\text { and Switzerland to conclude [..] government officials } \\
\text { said Monday. }\end{array}$ & $\begin{array}{l}19 \text { Feb. } 2009 \\
\text { / } 25 \text { Dec. } \\
2008\end{array}$ \\
\hline EC - Cote d'Ivoire & 26 Nov. 2008 & Deal & $\begin{array}{l}\text { Austria, Belgium, Bulgaria, } \\
\text { Czech Republic, Cote d'Ivoire, } \\
\text { Cyprus, Denmark, Estonia, } \\
\text { Finland, France, Germany, } \\
\text { Greece, Hungary, Ireland, } \\
\text { Italy, Latvia, Lithuania, } \\
\text { Luxembourg, Malta, } \\
\text { Netherlands, Poland, } \\
\text { Portugal, Romania, Slovak } \\
\text { Republic, Slovenia, Spain, } \\
\text { Sweden, United Kingdom }\end{array}$ & $\begin{array}{l}\text { Cote d'Ivoire became the first country in Africa to sign } \\
\text { an economic partnership agreement (EPA) with the } \\
\text { European Union [... formally copper-fastened in } \\
\text { Abidjan. }\end{array}$ & 26 Nov. 2008 \\
\hline
\end{tabular}

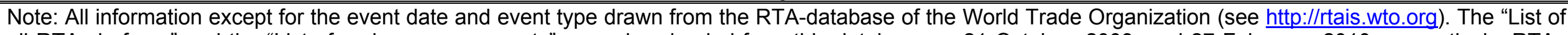

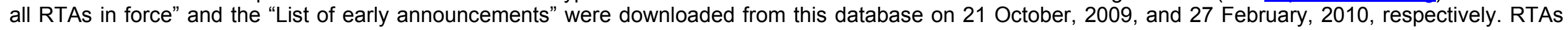

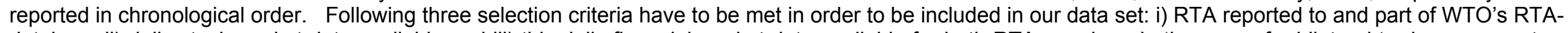

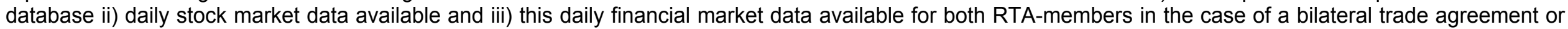

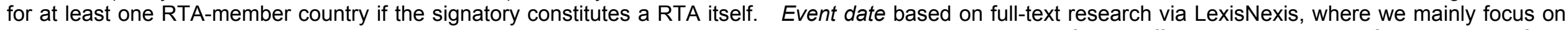

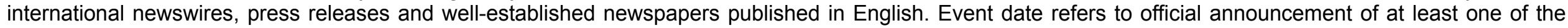

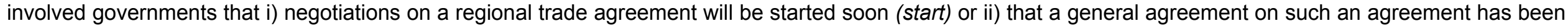

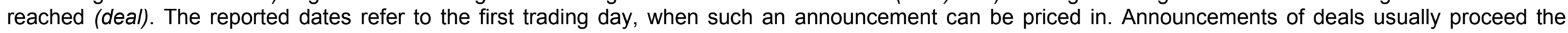

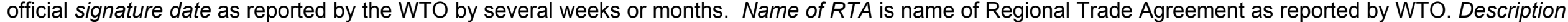
of Announcement gives some details on news. 
Table OA2: Raw Stock Market Returns of MSCI-World

\begin{tabular}{|c|c|c|c|c|c|}
\hline Type of stock market return & $(t-1, t+1)$ & $(t-1, t+3)$ & $(t-1, t+5)$ & $(t-1, t+7)$ & $(t-1, t+10)$ \\
\hline \multirow[t]{2}{*}{ Raw Returns of MSCI-World } & -0.095 & -0.108 & -0.088 & 0.058 & 0.146 \\
\hline & $(0.09)$ & $(0.18)$ & $(0.23)$ & $(0.30)$ & $(0.32)$ \\
\hline
\end{tabular}

Note: We report here the average raw returns for the market (MSCI-World) over the 199 event dates considered in this study. Event date defined as announcement of the start of negotiations of RTA or announcement of a successful conclusion of such an agreement. Standard errors in brackets are computed using the cross-section standard deviation of the returns and account for variance inflation and clustering at the announcement day. Returns significantly different from zero at [0.10] 0.05 (0.01) marked with [one circle] one (two) asterisk(s).

Table OA3: Evidence for Anticipation Effects?

\begin{tabular}{|c|c|c|c|c|c|}
\hline Model & $\begin{array}{c}\text { Default } \\
(t-1, t+5)\end{array}$ & $(t-3, t-1)$ & $(t-5, t-1)$ & $(\mathrm{t}-7, \mathrm{t}-1)$ & $(\mathrm{t}-10, \mathrm{t}-1)$ \\
\hline \multirow[t]{2}{*}{ Log real GDP p/c } & $-0.248^{*}$ & 0.017 & 0.027 & 0.056 & 0.105 \\
\hline & $(0.12)$ & $(0.12)$ & $(0.17)$ & $(0.18)$ & $(0.20)$ \\
\hline \multirow[t]{2}{*}{ Log real GDP } & 0.042 & -0.043 & -0.039 & -0.039 & -0.044 \\
\hline & $(0.08)$ & $(0.07)$ & $(0.10)$ & $(0.11)$ & $(0.13)$ \\
\hline \multirow[t]{2}{*}{ Log Trade/GDP } & -0.099 & -0.024 & -0.024 & -0.003 & -0.132 \\
\hline & $(0.16)$ & $(0.11)$ & $(0.16)$ & $(0.17)$ & $(0.23)$ \\
\hline \multirow[t]{2}{*}{ Log National Stocks/GDP } & 0.043 & -0.020 & -0.025 & -0.049 & -0.008 \\
\hline & $(0.08)$ & $(0.05)$ & $(0.08)$ & $(0.11)$ & $(0.13)$ \\
\hline \multirow[t]{2}{*}{ Exports to RTA partners/GDP } & $2.620 * *$ & -0.721 & -0.702 & 0.287 & 0.687 \\
\hline & $(0.79)$ & $(0.65)$ & $(0.66)$ & $(1.04)$ & $(1.11)$ \\
\hline \multirow[t]{2}{*}{ RTA-partner's log real GDP } & $-0.153^{* *}$ & 0.033 & -0.010 & -0.080 & -0.001 \\
\hline & $(0.06)$ & $(0.04)$ & $(0.05)$ & $(0.07)$ & $(0.08)$ \\
\hline Number of Observations & 1001 & 1001 & 1001 & 1001 & 1001 \\
\hline
\end{tabular}

Note: Each column is estimated via OLS. Estimates in Column (1) show the baseline results from Table 1 for comparability, covering 82 developing and developed countries and 122 RTAs from 1988 to 2009. In Column (2) to (5), we report the results for different event windows prior to the announcement date. Event date defined as announcement of the start of negotiations of RTA or announcement of a successful conclusion of such an agreement. Coefficients with standard errors clustered at the country-level in parentheses. Coefficients significantly different from zero at [0.10] 0.05 (0.01) marked with [one circle] one (two) asterisk(s). Regressand: National Stock Market return in local currency, adjusted for MSCI movement. Time-fixed effects, intercepts and Goods/Goods\&Services dummy included but not reported. 
Table OA4: Financial Market Expectations and Conditional Export Effects

\begin{tabular}{|l|c|c|c|c|c|}
\hline \hline Event window & $(\mathbf{t}-\mathbf{1}, \mathbf{t}+\mathbf{1})$ & $\mathbf{( t - 1 , \mathbf { t } + 5 )}$ & $\mathbf{( t - 1 , \mathbf { t } + \mathbf { 7 } )}$ & $\mathbf{( t - 1 , \mathbf { t } + 1 0 )}$ & $\mathbf{( t - 1 , \mathbf { t } + \mathbf { 1 5 } )}$ \\
\hline Gravity effect (fe) & 0.146 & $0.319^{*}$ & $0.452^{* *}$ & $0.529 * *$ & $0.477^{\circ}$ \\
\hline \hline & $(0.12)$ & $(0.14)$ & $(0.16)$ & $(0.19)$ & $(0.24)$ \\
\hline
\end{tabular}

Note: Each column is estimated via OLS. Estimates based on 970 observations, covering 80 developing and developed countries and 100 RTAs from 1988 to 2009. Event date defined as announcement of the start of negotiations of RTA or announcement of a successful conclusion of such an agreement. Coefficients with standard errors clustered at country-level in parentheses. Coefficients significantly different from zero at [0.10] 0.05 (0.01) marked with [one circle] one (two) asterisk(s). Regressand: National Stock Market return in local currency, betaadjusted for MSCI movement. The variable Gravity effect (fe) captures estimated RTA-specific coefficients from a bilateral trade model from 1988 to 2009 for all countries and all RTAs notified to WTO being in force (with timevarying importer and exporter fixed effects (2-years) and time-fixed effects).

\section{Table OA5: Changes in National Exchange Rate relative to U.S. Dollar}

\begin{tabular}{|l|c|c|c|c|c|}
\hline \hline Event window & $(\mathbf{t}-\mathbf{1}, \mathbf{t}+\mathbf{1})$ & $\mathbf{( t - 1 , \mathbf { t } + \mathbf { 3 } )}$ & $\mathbf{( t - 1 , \mathbf { t } + \mathbf { 5 } )}$ & $\mathbf{( t - 1 , \mathbf { t } + 7 )}$ & $\mathbf{( t - 1 , \mathbf { t } + 1 0 )}$ \\
\hline Log real GDP p/c & -0.013 & 0.000 & -0.008 & -0.055 & -0.109 \\
& $(0.03)$ & $(0.04)$ & $(0.04)$ & $(0.04)$ & $(0.06)$ \\
\hline Log real GDP & $0.054^{*}$ & 0.031 & $0.060^{*}$ & 0.053 & 0.061 \\
\hline & $(0.02)$ & $(0.03)$ & $(0.03)$ & $(0.04)$ & $(0.03)$ \\
\hline Log Trade/GDP & 0.090 & 0.153 & $0.203^{*}$ & 0.187 & 0.075 \\
\hline Log National Stocks/GDP & $(0.05)$ & $(0.08)$ & $(0.09)$ & $(0.11)$ & $(0.16)$ \\
\hline & $-0.059^{* *}$ & $-0.073^{*}$ & $-0.105^{* *}$ & -0.073 & -0.066 \\
\hline Exports to RTA partners/GDP & $(0.02)$ & $(0.03)$ & $(0.04)$ & $(0.04)$ & $(0.04)$ \\
\hline & -0.170 & -0.461 & -0.045 & $-0.990^{* *}$ & $-1.511^{* *}$ \\
\hline RTA-partner's log real GDP & $(0.28)$ & $(0.36)$ & $(0.39)$ & $(0.30)$ & $(0.36)$ \\
\hline & -0.008 & 0.017 & -0.002 & -0.027 & -0.017 \\
\hline \hline
\end{tabular}

Note: Each column is estimated via OLS. For comparability, sample restricted to sample of Appendix 3. Estimates based on 928 observations, covering 80 developing and developed countries and 122 RTAs from 1988 to 2009. Event date defined as announcement of the start of negotiations of RTA or announcement of a successful conclusion of such an agreement. Coefficients with standard errors clustered at country-level in parentheses. Coefficients significantly different from zero at [0.10] 0.05 (0.01) marked with [one circle] one (two) asterisk(s). Regressand: Change in National Exchange Rate relative to U.S. dollar. Positive (negative) sign equivalent to depreciation (appreciation) of exchange rate relative to U.S. dollar. Time-fixed effects, intercepts and Goods/Goods\&Services dummy included but not reported. 


\section{Appendix Graph 1: Second stage of Event Study (Coefficient on} log real GDP p.c. for Different CARs)

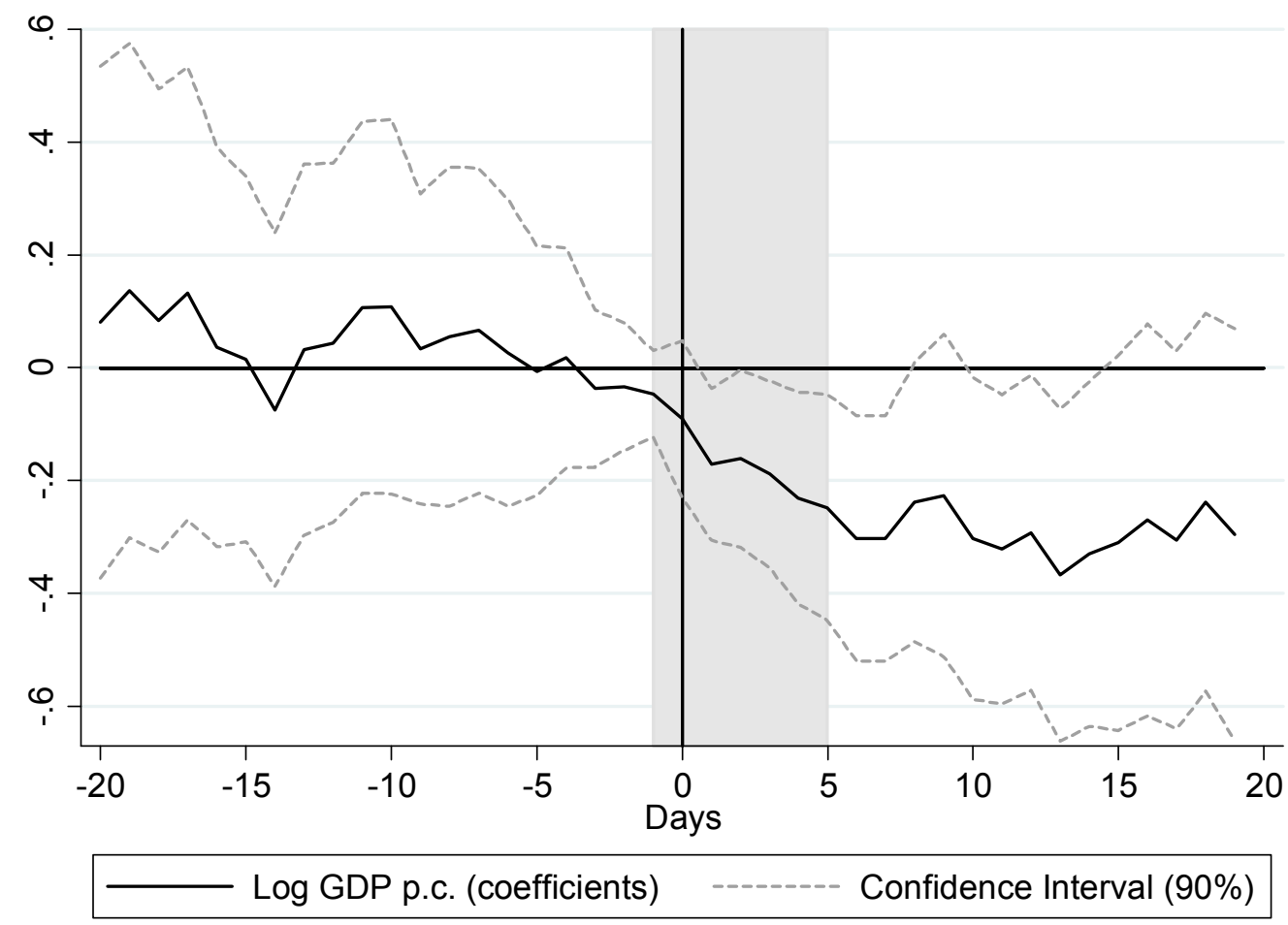

\section{Appendix Graph 2: Second stage of Event Study (Coefficient on Exports to RTA-partners for Different CARs)}

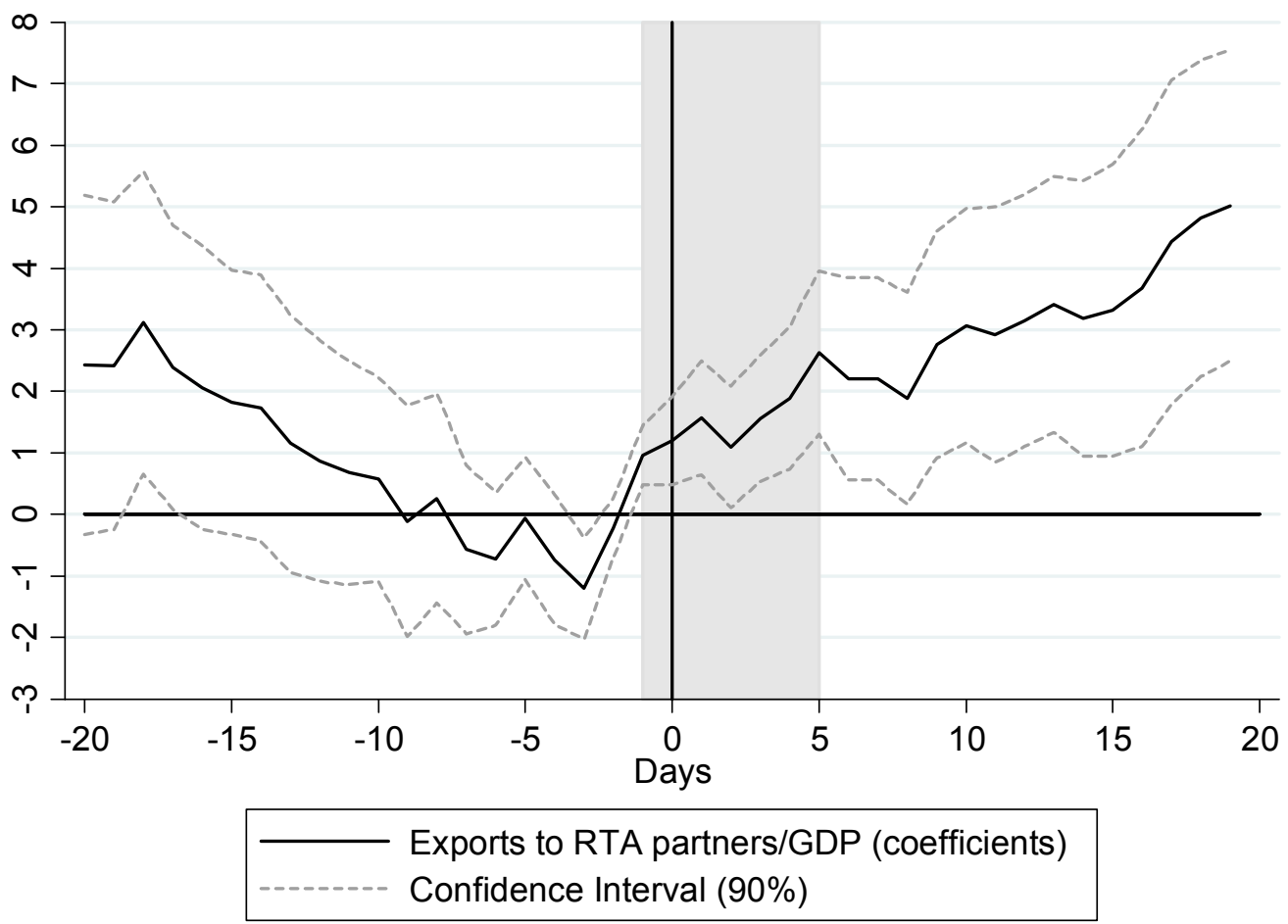


Appendix Graph 3: Second stage of Event Study (Coefficient on RTA-partner(s) log real GDP for Different CARs)

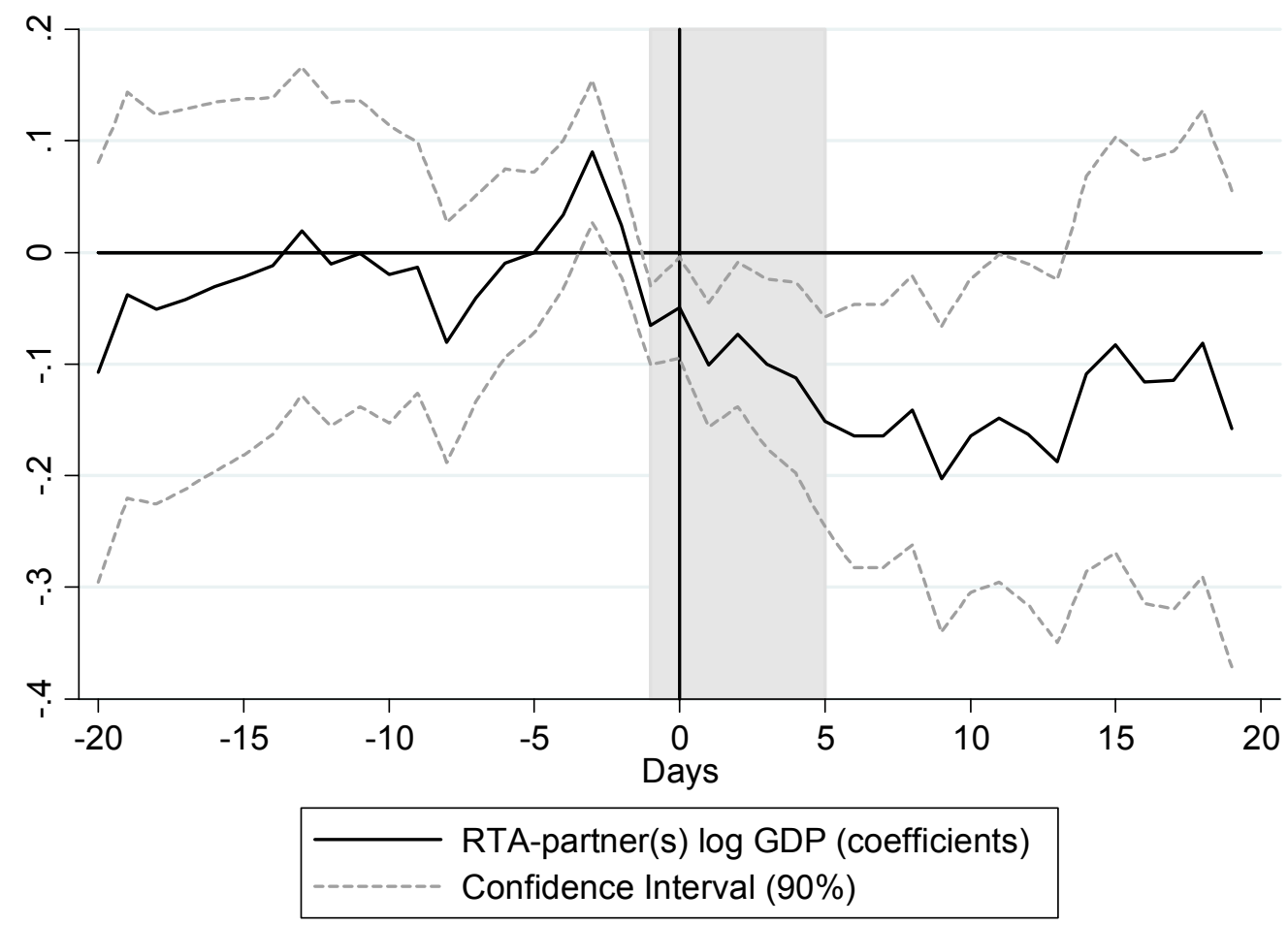




\section{Endnotes}

1 By "regional trade agreements" (RTAs), we include customs unions (CUs), free trade agreements (FTAs) and preferential trade agreements (PTAs). We do not distinguish between these forms; it is not easy to do so in practice, and all are allowed within the GATT/WTO framework.

2 Among others, Magee (2003, 2008), Baier and Bergstrand (2004, 2007, 2009), Carrère (2006), Eicher et al. (2012) and Egger et al. (2011) document the endogenous nature of regional trade agreements and their heterogeneous effects. Egger and Larch (2008) and Baldwin and Jaimovich (2012) emphasize the "spatial dimension" of trade agreements; if geographically close countries or important trading partners strike a deal with another country, the incentives for non-members to pursue a regional trade agreement increase.

${ }^{3}$ For evidence of limited capital mobility across sectors for the United States, Canada and (partly) Mexico see Grossman and Levinsohn (1989), Thompson (1994) and Rodriguez (2003). In Appendix Table A5, we proxy relative factor endowment by differences in real GDP per capita between RTA-partners (see Egger et al., 2011), but cannot find any significant effects.

4 For instance, Singapore's share prices initially dropped following the announcement of a RTA with the United States due to concerns about increased competition in the financial sector.

5 Joseph Stiglitz raises this concern for instance in the following newspaper articles: "New Trade Pacts Betray the Poorest Partners," Wall Street Journal, July 10, 2004; "Nobel Laureate Criticizes FTA, U.S. Unilateralism," The Korea Herald, Nov. 16, 2007.

${ }^{6}$ These are listed in the RTA-IS under "List of all RTAs in force" as well as those that have been signed but are not yet in force (listed in the RTA-IS under "List of early announcements").

${ }^{7}$ If the countries officially decide to conduct some sort of "pilot study" together, this announcement is defined as the official start of negotiations, so long as de facto negotiations are not conditional on the success of the pilot study.

${ }^{8}$ In the case of entry into the European Community/European Union, we define a "deal" as the European Commission's announcement to officially recommend the accession of a new member. While the European Council technically decides to accept this recommendation, the Council has never yet rejected a positive recommendation.

9 The full-text research via LexisNexis (LexisNexis Academic) was performed between October and December 2009, at the Haas Business School and between December 2009 and March 2010 at ETH Zurich. The full-text research typically starts with the key-words "free trade" or "trade agreement" and the two respective country names. We restrict ourselves to dates before the respective RTA went into force.

${ }^{10}$ One of the reasons for a gap between the official announcement and the signature ceremony is "legal scrubbing" since it usually takes some time to transform the political will of a general agreement into a contract. (We are not aware of any cases where an agreement has not been followed by the formal signing of a RTA.) A number of RTAs have been signed but not yet ratified at the time of gathering this data set; these RTAs had not yet been in force (prominent examples were the US-Korea and USColombia RTAs, which are ratified in the meanwhile).

11 In the interest of parsimony, we combine together RTA start and deal dates into a single data set, rather than modeling them separately. The hypothesis that the stock market responds equally to both types of news can neither be rejected for the first stage nor the second stage of the event study at any reasonable significance level (see Appendix Table A1 and A2).

12 Obviously, our results relate only to those firms actually listed in the stock market. Large firms are more likely to be publicly traded; they are also more likely to be exporters (e.g., Pagano et al, 1998; Bernard et al., 2007). Hence, the firms captured in our study are likely those most relevant for overall trade flows.

${ }^{13}$ Typically when we collect the same series from different sources (e.g., the EAFE index or the $\$ / C \$$ exchange rate), the series coincide closely.

${ }^{14}$ We exclude two extreme events from our analyses due to confounding factors. Argentina experience cumulative abnormal returns of nearly 40 percent around the announcement of a RTA with Brazil in 1991. But at the same time the Argentine Minister of Finance, Domingo Cavallo, also announced far-reaching economic policy reforms including the formation of a currency board. Furthermore, Vietnam suffered from heavy losses amidst the Subprime Crisis in autumn 2008 (up to -42 percent around the announcement of a RTA with Japan). Results are not sensitive to the inclusion of these two observations.

15 We have supplemented the sources below with national sources, if all but one control variable was missing for a country in an event-year. Our results are insensitive to the exclusion of these observations. 
${ }^{16}$ This is "a standard part of almost every event study [...] relevant even when the mean stock price effect of an event is zero" (Kothari and Warner, 2007).

${ }^{17}$ Our empirical strategy might entail measurement error in abnormal returns. To the extent that important news about RTAs is anticipated, our measured abnormal returns are biased towards zero. Prabhala (1997) demonstrates that standard event-study techniques remain valid. Our coefficients of interest $\{\gamma, \delta\}$ and their t-statistics then constitute a lower bound of the true value without any anticipation. Note that this potential downward bias could affect the first and the second stage of the event study. But anticipation effects do not seem to be a major issue here. To foresee some results: We neither find any strong movements in average abnormal returns before the RTA events (see Graph 1) nor can we explain the abnormal returns just prior to the RTA events with the set of variables employed in our main specification (see Online Appendix Table 3).

${ }^{18}$ Note that the variable "stocks traded relative to GDP" is only available from 1988. We also note in passing that we have experimented briefly (but unsuccessfully) with other regressors. For instance, in Appendix Table A5 a proxy for similarity between RTA-members is added (Baier and Bergstrand, 2004). Furthermore, another important variable from the trade gravity literature, namely distance, does not offer any additional insights (see also Appendix A6, Column 2).

19 The sibling of this variable, Imports from RTA partners/GDP, cannot be included separately due to multicollinearity.

${ }^{20}$ In the case of RTA-enlargements, the features of the RTA only refer to the new RTA partner(s).

${ }^{21}$ This effect is driven neither by differences in the number of listed firms between poor and rich countries nor corruption, as reported in Appendix A6, Columns 3 and 4.

22 In Appendix A6, Column 5, we replace exports to RTA partners by exports to and imports from RTA partners (still scaled by domestic GDP), yielding very similar results. Note that this alternative measure obviously has a higher mean and hence yields a smaller coefficient.

23 These positive stock market reactions for natural trading partners seem to be positively correlated with later on realized exports flows. We offer the following approach: We estimated a standard bilateral gravity model with RTA-specific effects (and time-varying exporter- and importer-effects, time-fixed effects and the usual suspects as control variables) for all countries from 1988 to 2009. We then correlate these RTAspecific coefficients (capturing the conditional export creating effect due to the RTA) with abnormal returns. Online Appendix 4 shows that they are positively and (starting from the event window $t-1, t+5$ ) significantly associated with each other.

${ }^{24}$ All these results are robust to the exact choice of window size for cumulative abnormal returns.

${ }^{25}$ Scaled abnormal returns are a preferred signal detection device, because noisier observations receive less weight than more reliable ones (Kolari and Pynnönen, 2010).

${ }^{26}$ Appendix Table A3 shows that our results are also insensitive to the exact sample of data; neither financial crisis periods nor outlier observations seem to drive our main results. The following time periods are defined as financial crises: Tequila Crisis (12/1994 and 1/1995), Asian Crisis (7/1997 to 12/1997), Russian Crisis and LTCM crisis (8/1998 to 12/1998), Argentine sovereign default (12/2001 and 1/2002) and onset of Subprime Crisis (8/2008 and 9/2008).

27 Appendix Tables A4 and Online Appendix 5 repeat the analysis of Table 1 for returns measured in US\$ and the LC/US\$ exchange rate respectively. Note that a negative coefficient on the variable Exports to RTA partners/GDP in Online Appendix 5 implies that the domestic currency tends to appreciate vis-àvis the US dollar if existing export links are already strong (for the longer event windows).

${ }^{28}$ Note that Exports to RTA partners/GDP here refers to exports from country $\mathrm{i}$ to the Top $\mathrm{x}$ export destination(s) relative to GDP in year t. 